\title{
Ginsenoside Compound K: Insights into Recent Studies on Pharmacokinetics and Health-Promoting Activities
}

\author{
Anshul Sharma ${ }^{1}$ and Hae-Jeung Lee ${ }^{1,2, * \mathbb{D}}$ \\ 1 Department of Food and Nutrition, College of Bionanotechnology, Gachon University, \\ Gyeonggi-do 13120, Korea; anshul.silb18@gmail.com \\ 2 Institute for Aging and Clinical Nutrition Research, Gachon University, Gyeonggi-do 13120, Korea \\ * Correspondence: skysea1010@gmail.com; Tel.: +82-31-750-5968; Fax: +82-31-724-4411
}

Received: 11 June 2020; Accepted: 7 July 2020; Published: 10 July 2020

check for updates

\begin{abstract}
Ginseng (Panax ginseng) is an herb popular for its medicinal and health properties. Compound $\mathrm{K}(\mathrm{CK})$ is a secondary ginsenoside biotransformed from major ginsenosides. Compound $\mathrm{K}$ is more bioavailable and soluble than its parent ginsenosides and hence of immense importance. The review summarizes health-promoting in vitro and in vivo studies of CK between 2015 and 2020, including hepatoprotective, anti-inflammatory, anti-atherosclerosis, anti-diabetic, anti-cancer, neuroprotective, anti-aging/skin protective, and others. Clinical trial data are minimal and are primarily based on CK-rich fermented ginseng. Besides, numerous preclinical and clinical studies indicating the pharmacokinetic behavior of $\mathrm{CK}$, its parent compound ( $\mathrm{Rb} 1)$, and processed ginseng extracts are also summarized. With the limited evidence available from animal and clinical studies, it can be stated that CK is safe and well-tolerated. However, lower water solubility, membrane permeability, and efflux significantly diminish the efficacy of CK and restrict its clinical application. We found that the use of nanocarriers and cyclodextrin for CK delivery could overcome these limitations as well as improve the health benefits associated with them. However, these derivatives have not been clinically evaluated, thus requiring a safety assessment for human therapy application. Future studies should be aimed at investigating clinical evidence of CK.
\end{abstract}

Keywords: ginseng; compound M1; hepatoprotective; anti-cancer; anti-inflammation; anti-diabetic; safety

\section{Introduction}

Ginseng (Panax ginseng) of the Araliaceae family is a perennial plant which has been conventionally used as a functional food. It is commonly consumed as a health supplement in Korea, Japan, China, the United Kingdom, Canada, Germany, France, and Austria [1]. Ginseng's bioactive constituents, including ginsenosides, phenolic compounds, and polysaccharides, have several medical uses [2]. Ginsenosides (or panaxosides) are the key pharmacologically significant bioactive constituents of ginseng. Nearly 150 ginsenosides isolated from roots, fruits, leaves, flower buds, processed items of ginseng, and other species have been identified [3]. A category of triterpene and saponin ginsenosides are divided into two forms: tetracyclic triterpenoids (four-ring dammarane type) and pentacyclic triterpenoids (five-ring oleanolic type) [4]. The dammarane type saponins are further categorized into protopanaxadiol (PPD) and protopanaxatriol (PPT) saponins [5]. The ginsenosides of PPD group constitute Compound K (CK), Rg3, Ra1, Ra3, Ra2, Rh2, Rb1, Rb3, Rb2, F2, Rc, and Rd, while PPT group constitutes of F1, Rg1, Rg2, Rf, Re, and Rh1 [3,6]. The oleanolic type saponins, such as Ro, are very low in concentration and thus rarely detected [4,6]. Examples of rare ginsenosides are CK, Rg3, F2, and $\mathrm{Rh} 2$, which are either absent in unprocessed ginseng or available at low concentrations [7]. It is 
well-known that compared to ginsenosides, their metabolite CK is absorbed well by the body and in lieu of this property, $\mathrm{CK}$ is becoming the fast focus of research [8].

Ginsenoside CK (G-CK; 20-O- $\beta$-D-glucopyranosyl-20(S)-protopanaxadiol) is a minor tetracyclic triterpenoid, also known as IH901, CK, and M1 [9]. Compound $\mathrm{K}$ is absent from natural ginseng and was isolated by researchers from Japan in 1972 by several biotransformation approaches from saponins such as $\mathrm{Rc}, \mathrm{Rb} 1$, and $\mathrm{Rb} 2$ [10]. The various processes used for the CK synthesis include enzymatic use [11], microbial conversion [3,4,12], heating [13], mycelial fermentation [14] and metabolic engineering [15]. The detailed procedure of biotransformation has been described in detail elsewhere [3]. Compound $\mathrm{K}$ is a major deglycosylated metabolite found in organs or blood after oral ingestion of PPD ginsenosides in the human gastrointestinal (GI) tract (Figure 1) [11]. The molecular weight and chemical formula of $\mathrm{CK}$ are $622.86 \mathrm{~g} / \mathrm{mol}$ and $\mathrm{C}_{36} \mathrm{H}_{62} \mathrm{O}_{8}$, respectively [16].

A review by Yang et al. [11] described in detail the biotransformation of CK and recorded its pharmacological activities until 2014. Another review [3] compiled information on the biotransformation and pharmacokinetics of $\mathrm{CK}$, including the positive effects on neuroprotection and cognitive improvement by 2016. Like the previously published reviews, this paper documents recent papers targeting hepatoprotective, anti-inflammatory, anti-atherosclerosis, anti-diabetic, anti-cancer, neuroprotective, anti-aging/skin protective effects published from 2015 to 2020 . This review, however, differs significantly from previous works, including detailed information on preclinical and clinical pharmacokinetic studies and the inclusion of anti-asthmatic and kidney-protective effects among others in vitro and in vivo activities of CK. Additionally, data are also integrated on several CK derivatives with improved solubility and health-promoting activities. Finally, recently published clinical studies are also summarized. Herein, we briefly discuss the recent reports on the pharmacokinetics and health effects of CK and elucidate on how the modification of CK improves metabolic properties, pharmacokinetics, and bioactivities of CK.

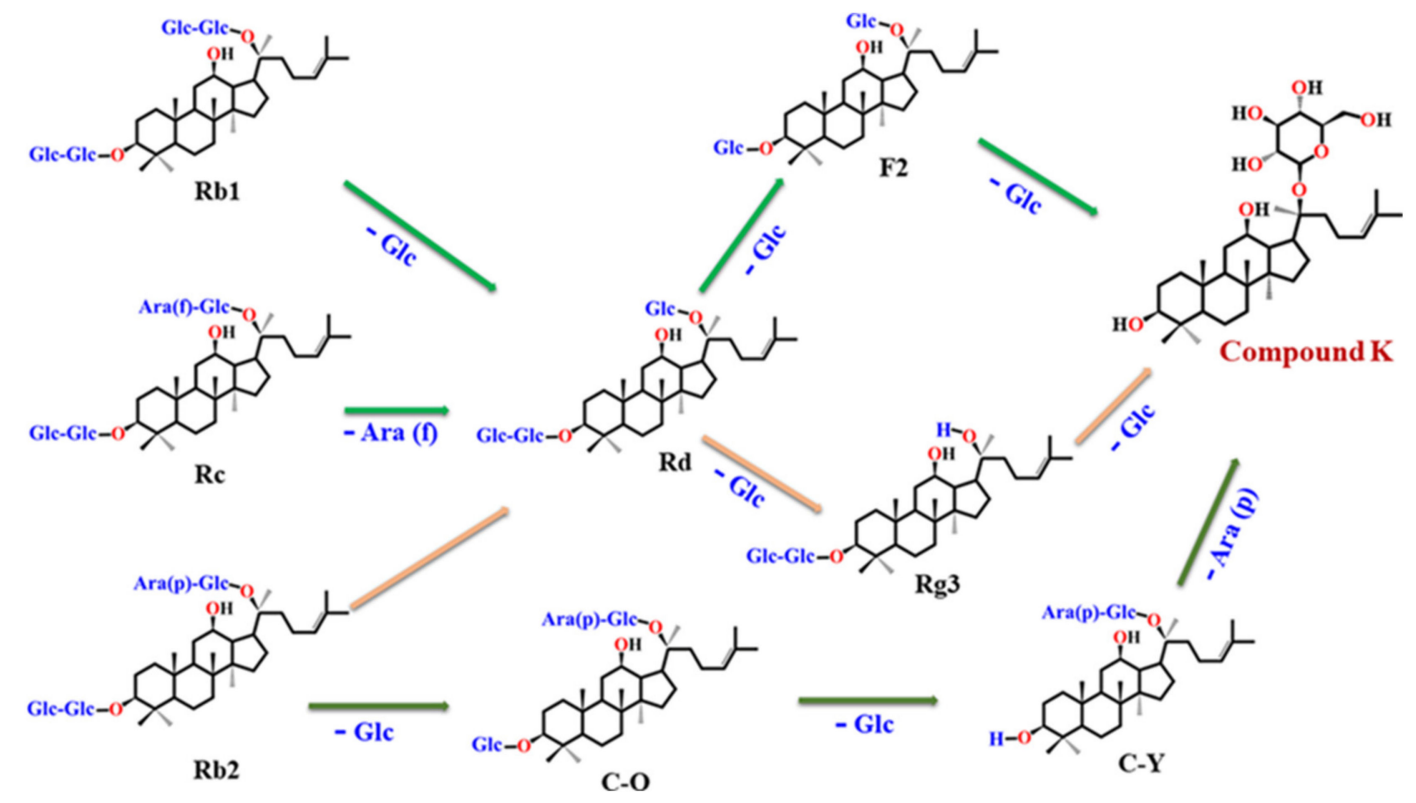

Figure 1. Schematic illustration of plausible biotransformation of major ginsenosides $\mathrm{Rb} 1, \mathrm{Rb} 2 \mathrm{and} \mathrm{Rc}$ to compound $\mathrm{K}$.

\section{Literature Search}

A precise literature search was carried out with Google Scholar, PubMed, and the Science Direct repositories for related findings between January 2015 and May 2020. The following keywords: "Ginsenoside compound K" or "Compound K" or "20-O-D-glucopyranosyl-20(S)-protopanaxadiol" or "IH901" or "M1" or "health-promoting activities of compound K," or "Ginsenoside Compound K and 
pharmacokinetics," "Compound M1," and "fermented ginseng," were used to find all the relevant literature published on CK, its pharmacological activities, and modifications conferred on its structure so as to augment solubility and bio permeability.

\section{Pharmacokinetics, Metabolism and Safety of Compound K}

Compound $\mathrm{K}$ has recently been the focus of research for its bioactivities; however, little is known about its pharmacokinetic behavior, solubility, bioavailability and safety.

\subsection{Preclinical Perspective (Pharmacokinetic)}

It is important to have an in-depth knowledge of how pro-and prebiotics affect adsorption, distribution, metabolism, and excretion (ADME) of drugs. In this line, the effect of prebiotic fiber (NUTRIOSE ${ }^{\circledR}$ ) on the pharmacokinetic behavior of CK was investigated using Sprague-Dawley (SD) rats. NUTRIOSE ${ }^{\circledR}$ treatment displayed a dose-dependent rise in plasma concentration $\left(C_{\max }\right)$, area under the plasma concentration-time curve (AUC), and a decrease in time of maximum concentration $\left(\mathrm{T}_{\max }\right)$ values compared to control. Moreover, the increased glycosidase activity led to the synthesis of $\mathrm{CK}$ in the internal intestinal constituents. In addition, NUTRIOSE ${ }^{\circledR}$ has substantially triggered the biotransformation of CK by in vitro grown gut microbiota [17]. This study was in par with earlier findings wherein gut microbiome and diet were reported for possible effects on the concentration of CK in plasma $[8,18]$.

In a study, fermented and non-fermented red ginseng extracts were administered to SD rats. Based on the pharmacokinetics parameters, CK absorption was found to be more in the fermented group than non-fermented group (Table 1) [19]. In another study, the pharmacokinetics of the oral administration of $P$. ginseng extract was evaluated in plasma, urine, and fecal samples using SD rats. The study used liquid chromatography (LC)-mass spectrometry (MS)/MS for identifying and quantifying major saponins and their metabolites present in . ginseng extract. The $C_{\max }, T_{\max }$, and AUC, were significantly higher for CK (in rat plasma) compared to other ginsenosides, including $\operatorname{Re}, \operatorname{Rg} 1$, Rc, Rf, Rb1, Rg2, Rb2, Rd, F1, and F2. The study for the first time documented the comprehensive pharmacokinetics of ginsenosides and their metabolites following oral intake of P. ginseng. Earlier studies documented the pharmacokinetic properties of several individual ginsenosides only [20].

In another study from Japan, the oral pharmacokinetic behavior of $\mathrm{CK} /$ gamma-cyclodextrin $(\mathrm{K} / \gamma-\mathrm{CyD}, 1: 1)$ in SD rats has been described. The strong dissolution behavior of $\mathrm{CK}(\mathrm{K} / \gamma-\mathrm{CyD})$ was attributed to a higher significant change in $C_{\max }$, AUC values and a lower $T_{\max }$ compared with $C K$ and $\mathrm{K} / \beta-\mathrm{CyD}$ (Table 1$)$. The stability constant for $(\mathrm{K} / \gamma-\mathrm{CyD}, 1: 1)$ complex was 18 times $\left(1.5 \times 10^{5} \mathrm{M}^{-1}\right)$ than that of the $\beta$-CyD complex $\left(8.2 \times 10^{3} \mathrm{M}^{-1}\right)$. The compound-complex $(\mathrm{K} / \gamma-\mathrm{CyD}, 1: 1)$ displayed a faster dissolution rate compared to $\mathrm{K} / \gamma-\mathrm{CyD}$ complex at 1:3 ratios. The study concluded that partial inclusion complexes are more advantageous for improving the solubility of CK compared to complete inclusion [21].

\subsection{Clinical Perspective (Pharmacokinetic)}

Previously, the pharmacokinetics of CK was studied as part of the ingestion of whole ginseng extract. In one study, the intake of fermented red ginseng extract showed a higher concentration (more than 10 times) of CK in plasma compared to its unfermented counterpart in a study of healthy Korean volunteers. In the fermented group, AUC was 15.5-fold higher than the non-fermented group, and the mean $C_{\max }$ was 27 -fold higher compared to the unfermented group. A lower $\mathrm{T}_{\max }$ was observed in the fermented group than non-fermented group (Table 1). Compared to a previous study [22] where subjects were administered with $5 \mathrm{~g}$ of Korean red ginseng, this study showed larger AUC, higher $\mathrm{C}_{\max }$, and longer $\mathrm{T}_{\max }$ values with lower $(3 \mathrm{~g})$ amount of fermented red ginseng. The authors described the differences in the pharmacokinetic parameters plausibly due to different methods used for fermentation of red ginseng. Of note, the study also confirmed these effects in vivo and found absorption of CK was more in humans compared to rats. The study also highlighted that absorption of CK depends upon the 
interspecies variability between humans and rats [19]. It has also been reported that the fermentation of white ginseng had less effect on CK absorption compared with red ginseng fermentation [23].

Likewise, another study compared the pharmacokinetics of CK after oral administering fermented ginseng (FG, by Lactobacillus (L.) paracasei A221) and non-fermented ginseng (NFG) in healthy Japanese adults. A higher $C_{\max }$ and a lower $T_{\max }$ value of $C K$ was observed for FG compared to NFG (Table 1 ). The mean AUC value from 0 to $12 \mathrm{~h}$ was 58.3 -times, and AUC value from 0 to $24 \mathrm{~h}$ was 17.5 -times higher than the NFG. Furthermore, following $24 \mathrm{~h}$ supplementation, the mean concentration of testosterone was increased significantly in the male subjects treated with FG [24]. The findings concluded that the transformation of ginseng extract by L. paracasei A221 resulted in improved health in Japanese subjects. This is the first research on Japanese subjects which evaluates the health properties of $P$. ginseng. The positive bio transforming role of L. paracasei A221 modulating bioavailability and functional aspects has also been described [25]. In recent research, LC-MS was used to spot 13 ginsenosides in the human plasma following two-week recurrent supplementation of red ginseng extract. Among 13 ginsenosides, $\mathrm{CK}, \mathrm{Rh} 2, \mathrm{PPD}$, and PPT were detected in the subject's plasma, although initially not presented in red ginseng extract, suggesting the formation of these ginsenosides after bioconversion in the GI tract. The $C_{\max }, T_{\max }$, and AUC values were found to be higher for $C K$ among 13 ginsenosides. The authors further identified a large variation in the concentration of $\mathrm{CK}$ among subjects owing to their metabolic differences associated with microorganisms of the GI tract (Table 1) [26].

In a recent randomized, open-label, single-sequence study, the participants were administered with the red ginseng product of a single dose and two-week repeated dose. The quantities of CK, Rc, $\mathrm{Rb} 1, \mathrm{Rd}$, and $\mathrm{Rb} 2$ ginsenosides in plasma of the human subjects were measured. Of the 15 participants, three subjects revealed higher plasma levels of $C K$ and $R d$, suggesting higher bioconversion of $R b 1, R b 2$, and $\mathrm{Rc}$ to $\mathrm{Rd}$ and then to $\mathrm{CK}$. The study showed that the multiple-dose of red ginseng extract did not boost the AUC and $\mathrm{C}_{\max }$ values, leading to low accumulation of $\mathrm{CK}$ (compared to other ginsenosides) in plasma, due to the comparatively short half-life of CK (Table 1). Furthermore, the AUC values of $\mathrm{CK}$ and Rd were significantly correlated irrespective of the dose amount. These results suggest the upstream biotransformation of saponins and have found that the repeated dose of CK is healthy for human consumption [27].

Apart from ginseng extracts or a mixture of ginsenosides, the pharmacokinetics of monomer CK has also been described [28,29]. In one study, LC-MS/MS (positive ion mode) with lithium adducts, was used to measure CK concentration in plasma of healthy Chinese subjects. Adducts were intended to boost the MS functionality. The method used was found to be perfect, reproducible and precise compared to the LC-MS/MS (negative ion mode) study reported earlier [22] for CK determination in human plasma. In addition, the lower limit of quantification was achieved by using smaller concentrations $(50 \mu \mathrm{L})$ compared to higher human plasma levels $(100 \mu \mathrm{L})$ [29]. An open-label, single-center, randomized, two-period crossover trial found that high-fat food consumption with CK decreased its $\mathrm{T}_{\max }$ value and increased its values for $\mathrm{C}_{\max }$ and AUC relative to the overnight fasting community (Table 1). Moreover, in females, the CK consumption was higher than in males. These results suggest that both food (high-fat diet) and sex affect the pharmacokinetics of CK and its metabolite, 20(S)-PPD. Such findings revealed preliminary pharmacokinetics of pure $\mathrm{CK}$ and its metabolite. To make a stronger conclusion, further research through large population size and daily diet record should be implemented [28]. Another recent, randomized, single-center, open-label, two-period crossover trial study first applied and validated LC-MS/MS to govern the pharmacokinetics of CK and its 20 (S)-PPD metabolites present in plasma and urine samples of healthy Chinese volunteers (Table 1) [30]. 
Table 1. Pharmacokinetics of CK and its derivatives.

\begin{tabular}{|c|c|c|c|c|c|c|c|c|c|c|}
\hline \multirow[t]{2}{*}{ Subject } & \multirow[t]{2}{*}{ Compound } & \multirow[t]{2}{*}{ Dose } & \multirow[b]{2}{*}{$\mathrm{C}_{\max }(\mathrm{ng} / \mathrm{mL})$} & \multirow[b]{2}{*}{$\mathrm{T}_{\max }(\mathrm{h})$} & \multicolumn{4}{|c|}{ Pharmacokinetics Parameters } & \multirow[b]{2}{*}{$\mathrm{T}_{1 / 2}(\mathrm{~h})$} & \multirow[t]{2}{*}{ Ref } \\
\hline & & & & & AUC (ng.h/mL) & V/F (L) & MRT (h) & $\mathrm{CL} / \mathrm{F}\left(\mathrm{L} \cdot \mathrm{h}^{-1}\right)$ & & \\
\hline \multicolumn{11}{|c|}{ Preclinical Studies } \\
\hline \multirow[t]{4}{*}{ SD rats } & GE (N0-G) & $2000 \mathrm{mg} / \mathrm{kg}$ & $24.1 \pm 5.5$ & $15.2 \pm 1.8$ & $153.1 \pm 30.6$ & & & & & [17] \\
\hline & $\mathrm{GE} \pm 2.5 \% \mathrm{~N}$ & & $24.0 \pm 9.3$ & $12.8 \pm 3.3$ & $187.2 \pm 24.0$ & & & & & \\
\hline & $\mathrm{GE} \pm 5 \% \mathrm{~N}$ & & $38.8 \pm 21.8$ & $12.0 \pm 0.0$ & $218.5 \pm 60.7$ & & & & & \\
\hline & $\mathrm{GE} \pm 10 \% \mathrm{~N}$ & & $54.4 \pm 26.2$ & $12.0 \pm 0.0$ & $429.9 \pm 160.8$ & & & & & \\
\hline \multirow[t]{2}{*}{ SD rats } & HYFRG ${ }^{\mathrm{TM}} * * *$ & $500 \mathrm{mg} / \mathrm{kg}$ & $15.19 \pm 10.69$ & $3.3 \pm 0.5$ & $58.0 \pm 32.5$ & & & & & [19] \\
\hline & CK from RG & $500 \mathrm{mg} / \mathrm{kg}$ & $2.55 \pm 0.99$ & $6.7 \pm 3.9$ & $9.2 \pm 7.5$ & & & & & \\
\hline SD rats & CK from $P G$ \# & $100 \mathrm{mg} / \mathrm{kg}$ & $1888.9 \pm 403.0$ & $8.2 \pm 1.7$ & $24.0 \pm 6.0$ & & $13.9 \pm 5.2$ & & $10.2 \pm 8.1$ & [20] \\
\hline \multirow[t]{4}{*}{ SD rats } & CK & $30 \mathrm{mg} / \mathrm{kg}$ & $192.3 \pm 40.7$ & $2.2 \pm 0.5$ & $622.3 \pm 240.7$ & & $3.8 \pm 0.8$ & & & {$[21]$} \\
\hline & $\begin{array}{c}\mathrm{CK} / \gamma-\mathrm{CyD} \\
(1: 1)\end{array}$ & & $366.7 \pm 102.5$ & $1.8 \pm 0.1$ & $907.3 \pm 111.1$ & & $2.5 \pm 0.2$ & & & \\
\hline & $\begin{array}{c}\mathrm{CK} / \gamma-\mathrm{CyD} \\
(1: 3)\end{array}$ & & $476.0 \pm 81.5$ & $1.5 \pm 0.2$ & $1074.8 \pm 32.9$ & & $2.2 \pm 0.0$ & & & \\
\hline & $\begin{array}{c}C K / \beta-C y D \\
(1: 1)\end{array}$ & & $204.0 \pm 30.8$ & $2.0 \pm 0.4$ & $867.0 \pm 69.6$ & & $3.3 \pm 0.5$ & & & \\
\hline \multicolumn{11}{|c|}{ Clinical Studies } \\
\hline \multirow[t]{2}{*}{$24 \mathrm{M}$} & HYFRG $^{\mathrm{TM}}$ & $3 \mathrm{~g}$ & $254.4 \pm 51.2$ & $2.5 \pm 0.9$ & $1466.83 \pm 295.89$ & & & & & [19] \\
\hline & RG & $3 \mathrm{~g}$ & $3.1 \pm 1.7$ & $9.1 \pm 1.4$ & $12.73 \pm 7.83$ & & & & & \\
\hline \multirow[t]{2}{*}{$12 \mathrm{M} / \mathrm{F}$} & FG & $1.65 \mathrm{~g}$ & $41.5 \pm 21.8$ & $2.2 \pm 0.6$ & $\begin{array}{c}204 \pm 94(0-12 \mathrm{~h}) \\
238 \pm 105(0-24 \mathrm{~h}) \\
264 \pm 113 \$\end{array}$ & & $9.9 \pm 5.5$ & & $10 \pm 5$ & [24] \\
\hline & NFG & & $1.1 \pm 0.7$ & $16 \pm 7.0$ & $\begin{array}{c}3.5 \pm 3.1(0-12 \mathrm{~h}) \\
13.6 \pm 9.3(0-24 \mathrm{~h}) \\
\text { NC }\end{array}$ & & NC & & $\mathrm{NC}$ & \\
\hline $11 \mathrm{M}$ & RG extract $\# \#$ & Multiple & $81.6 \pm 112.5$ & $9.5 \pm 1.6$ & $873.0 \pm 1236.0$ & & $10.6 \pm 1.2$ & & $5.2 \pm 1.1$ & [26] \\
\hline \multirow[t]{2}{*}{$15 \mathrm{M}$} & RG extract \#\#\# & Single & $24.8 \pm 23.2$ & $7.8 \pm 2.0$ & $247.50 \pm 269.49$ & & $13.3 \pm 3.7$ & & $9.9 \pm 4.9$ & [27] \\
\hline & & Multiple & $18.2 \pm 27.1$ & $6.9 \pm 2.4$ & $210.88 \pm 400.44$ & & $10.5 \pm 3.1$ & & $7.6 \pm 4.1$ & \\
\hline
\end{tabular}


Table 1. Cont.

\begin{tabular}{|c|c|c|c|c|c|c|c|c|c|c|}
\hline \multirow[t]{2}{*}{ Subject } & \multirow[t]{2}{*}{ Compound } & \multirow[t]{2}{*}{ Dose } & \multirow[b]{2}{*}{$\mathrm{C}_{\max }(\mathrm{ng} / \mathrm{mL})$} & \multirow[b]{2}{*}{$\mathrm{T}_{\max }(\mathrm{h})$} & \multicolumn{5}{|c|}{ Pharmacokinetics Parameters } & \multirow[t]{2}{*}{ Ref } \\
\hline & & & & & AUC (ng.h/mL) & $\mathrm{V} / \mathrm{F}(\mathrm{L})$ & MRT (h) & $\mathrm{CL} / \mathrm{F}\left(\mathrm{L} \cdot \mathrm{h}^{-1}\right)$ & $\mathrm{T}_{1 / 2}(\mathrm{~h})$ & \\
\hline \multirow[t]{2}{*}{$24 \mathrm{M} / \mathrm{F}$} & $\mathrm{CK}+\mathrm{HF}$ diet & $200 \mathrm{mg}$ & $1,570.3 \pm 587.3$ & $2.5(1.5-5.0)$ & $\begin{array}{c}12,599.2 \pm 4098.3^{\$} \\
12,836.7 \pm 4166.2^{\$ \$}\end{array}$ & $652 \pm 381$ & $\begin{array}{c}12.3 \pm 1.2^{\$} \\
14.6 \pm 1.7^{\$ \$}\end{array}$ & $18.2 \pm 9.8$ & $24.8 \pm 3.0$ & [28] \\
\hline & $\mathrm{CK}+\mathrm{FO}$ diet & & $796.8 \pm 406.0$ & $3.6(2.0-6.0)$ & $\begin{array}{l}5748.7 \pm 2830.2 \$ \\
5879.3 \pm 2871.0 \$\end{array}$ & $1875 \pm 1899$ & $\begin{array}{l}11.7 \pm 1.2^{\$} \\
15.1 \pm 4.3^{\$ \$}\end{array}$ & $43.4 \pm 24.2$ & $27.7 \pm 7.9$ & \\
\hline $12 \mathrm{M} / \mathrm{F}$ & GCK & $50 \mathrm{mg}$ & $652 \pm 180$ & $2.6 \pm 1.1$ & $\begin{array}{l}3650 \pm 850 \text { \$; } \\
3810 \pm 890^{\$ \$}\end{array}$ & & & & $5.9 \pm 0.6$ & [29] \\
\hline 10 adults & CK & $200 \mathrm{mg}$ & $733.9 \pm 408.4$ & $3.3(2.5-5.0)$ & $\begin{array}{l}5960.8 \pm 3524.4^{\$} \\
6094.2 \pm 3598.4^{\$ \$}\end{array}$ & & $\begin{array}{l}11.5 \pm 1.4^{\$} \\
13.8 \pm 1.6^{\$ \$}\end{array}$ & & $21.6 \pm 5.5$ & {$[30]$} \\
\hline
\end{tabular}

*** The study was conducted on both rats and humans. \# analysis was compared with other ginsenosides, including Rb1, Rb2, Rc, Rd, Re, Rg1, Rg2, Rf, F1 and F2. \#\# RG extract dose protopanaxadiol (PPD)-50.2-64.7 mg/day and protopanaxatriol (PPT), 11.2-14.9 mg/day. Multiple (3 Pouches). CK was compared with Rb1, Rb2, Rc, Rd, Rg3, Rh2, PPD, and PPT. $\mathrm{K} ; \mathrm{C}_{\max }$, maximum drug concentration; $\mathrm{T}_{\max }$, time of maximum concentration; $\mathrm{AUC}$, area under the plasma concentration-time curve; $\mathrm{V} / \mathrm{F}$, apparent volume of distribution after extravascular administration MRT, mean residence time; $\mathrm{CL} / \mathrm{F}$, oral clearance; $\mathrm{T}_{1 / 2}$, half-life. Each value represents the mean $\pm \mathrm{SE}$ of three samples. SD, Sprague Dawley; $\mathrm{GE}$, ginseng extract; N, NUTRIOSE; HYFRG ${ }^{\mathrm{TM}}$, CK from fermented RG extract; RG, red ginseng; PG, Panax ginseng; M., Male; F, female; FG, fermented ginseng (fermented using Lactobacillus paracasei A221); NFG, non-fermented ginseng; NC, not-calculated; GCK, ginsenoside CK; AUC (0-th), AUC from zero to the time of the last quantifiable concentration; AUC $(0-\infty)$, AUC from zero to A221); NFG, non-fermented ginseng; NC, not-calculated; $\mathrm{GCK}$, ginsenoside $\mathrm{CK}$; $\mathrm{AUC}$ (0-th), $\mathrm{AUC}$ from zero to the time of the last quantifiable concentration; $\mathrm{AUC}(0-\infty \mathrm{h}), \mathrm{AUC}_{\text {from zero to }}$ infinity; HF, high fat; FO, fasting overnight. 
Furthermore, a study on healthy Chinese participants has established the relationship between ABCB1 gene polymorphisms and CK pharmacokinetics. The results indicated that the gene NR1I2 (rs1464602 and rs2472682) allied primarily to the pharmacokinetics of CK. While ABCC4 (rs1751034 and rs1189437) influenced the pharmacokinetic behavior of both CK and its metabolite 20(S)-PPD. Such hereditary variations could thus partially describe the inter-individual variances in the pharmacokinetic behavior of CK [31].

\subsection{Solubility, Permeability, and Efflux}

Many health-promoting activities of CK have been reported. However, low water solubility, low membrane permeability, and efflux phenomenon critically weaken its efficacy and restrict its clinical application. The use of cyclodextrin (CyD) and nanocarriers have been implemented to improve the bioavailability of CK. Table 2 summarizes various modifications of CK with their outcomes.

The use of CyD has been duly recognized to improve the pharmacological behavior of drugs. In this line, an inclusion complex, $\mathrm{K} / \gamma-\mathrm{CyD}$, with improved oral bioavailability and solubility [21], compared to an earlier finding (in $\beta-\mathrm{CyD}$ only solubility was improved) has been described [32]. In another study, the use of ginsenoside CK with TPGS (D-alpha-tocopheryl polyethylene glycol (PEG) 1000 succinate) (GCKT)-liposomes has been described to improve solubility, targeting tumor cells, and minimizing efflux. The D-alpha-tocopheryl polyethylene glycol (PEG) 1000 succinate and phospholipid could increase the solubility of CK in the form of GCKT-liposome, leading to significant repression of tumor growth [33]. Phospholipid use improves biocompatibility, which could restore permeability and increase the process of ADME [34]. The D-alpha-tocopheryl polyethylene glycol (PEG) 1000 succinate has widely been documented as an inhibitor of P-glycoprotein (P-gp)-mediated efflux in drug delivery systems [35], and P-gp-mediated efflux was reported to be a significant limiting factor for the efficacy of CK [36].

In another study, CK-micelles (CK-M) from TPGS, PEG, and PCL (polycaprolactone) showed enhanced solubility and improved bioactivities. After $48 \mathrm{~h}$, the $\mathrm{CK}$ was released slowly from $\mathrm{CK}-\mathrm{M}$ with a drug release percentage of more than $42.1 \pm 3.2 \%$ and without bursting. In the first eight hours, the rate of in vitro drug release for free CK with bursting was $84.4 \pm 4.2 \%$. Additionally, the P-gp-mediated efflux in the CK-M group was substantially inhibited compared to free CK, suggesting drug uptake by the target cells [36]. Likewise, CK ascorbyl palmitate (AP)/TPGS micelles enhanced solubility of CK and significantly inhibited P-gp-mediated efflux [37]. Similarly, the micellar system based on phosphatidylcholine (PC) and 1,2-distearoyl-sn-glycero-3-phosphoethanolamine polyethylene glycol 2000 (DP) showed improved solubility and continued release of CK [38]. The water solubility of the CK nanoparticles (NPs)/bovine serum albumin (BSA) and CK, was compared, and BSA was found to augment the water solubility of CK. The high biocompatibility, dispersive nature, and conjugative ability to several target molecules make BSA a useful carrier molecule [39].

In another study, CK was loaded onto gold(G)NPs synthesized using probiotic bacteria (Lactobacillus kimchicus DCY $51^{\mathrm{T}}$ ) and evaluated for the effectiveness of drug loading [40]. Furthermore, the use of deoxycholic acid (DA)-O-carboxymethyl chitosan (OCMC) has been advocated to increase solubility and ability for CK. For example, CK-NPs conjugated with DA-OCMC showed increased solubility and improved drug entrapping and drug loading efficiencies. The release pattern of CK was $\mathrm{pH}$-dependent and faster at lower $\mathrm{pH}$. The collective release of $\mathrm{CK}$ at $\mathrm{pH} 7.4$ and 5.8 was $10.7 \pm 0.71 \%$, and $16.3 \pm 1.4 \%$, respectively, after the first $48 \mathrm{~h}$, without bursting. Notably, over $120 \mathrm{~h}$ of the study, a significant increase in the release of $\mathrm{CK}$ was observed. These findings indicate that CK was released slowly (the pH of blood), thus the system could be used for target delivery of CK [41]. 
Table 2. Solubility, permeability, and efflux of CK and its derivatives.

\begin{tabular}{|c|c|c|c|}
\hline Modified CK & Model & Major Findings & Ref. \\
\hline $\mathrm{K} / \gamma-\mathrm{CyD}$ and $\mathrm{K} / \beta-\mathrm{CyD}$ & $\begin{array}{l}\mathrm{K} / \gamma-\mathrm{CyD} \text { at different ratios } 1: 1 \text { and } 1: 3 \text { and } \mathrm{K} / \beta-\mathrm{CyD} \\
\text { at } 1: 1\end{array}$ & $\begin{array}{l}\text { Improved solubility at lower concentrations }(<0.03 \mathrm{M}) \text { compared to higher } \\
\qquad \begin{array}{c}(<0.06 \mathrm{M}) \\
\uparrow \text { bioavailability }\end{array} \\
\uparrow \text { dissolution rate compared to CK and } \mathrm{K} / \beta-\mathrm{CyD} \\
\text { Higher dissolution rate in } 1: 1 \text { ratio compared to } 1: 3\end{array}$ & {$[21]$} \\
\hline GCKT-liposomes & Phospholipid and TPGS (7:3 ratio) & $\begin{array}{c}\text { THigh CK loading capacity and solubility } \\
\text { GCK EE } \% \text { was of above } 98.4 \pm 2.3 \% \\
\text { Sustained discharge of GCK from GCKT-liposomes compared to GCK } \\
\text { solution (in PBS) }\end{array}$ & {$[33]$} \\
\hline CK-M & $\begin{array}{l}\text { PEG-PCL/TPGS mixed micelles at different ratios of } \\
\text { 3:0. 3:1, 3:2, } 3: 3\end{array}$ & $\begin{array}{c}\uparrow \text { drug EE\% in CK-M }(94.6 \pm 1.4) \text { than CK-P }(62.5 \pm 1.6 \text {; PEG-PCL micelles) } \\
\uparrow C K \text { concentration (107.3-times) in micelles (CK-M) than free CK } \\
\uparrow \text { solubility of CK with higher TPGS }\end{array}$ & {$[36]$} \\
\hline CK-AP/TPGS micelles & AP/TPGS mixed micelles & $\begin{array}{c}\uparrow \text { solubility from } 35.2 \pm 4.3 \text { to } 1,463.2 \pm 153.3 \mu \mathrm{g} / \mathrm{mL} \text { of } \mathrm{CK} \\
\text { EE } \%=91.3 \pm 5.2 \% \\
\text { Inhibited P-gp mediated efflux }\end{array}$ & [37] \\
\hline CK PC/DP micellar system & $\mathrm{CK}, \mathrm{DP}$, and $\mathrm{PC}$ at ratios of 5:12:18 & $\uparrow$ water solubility ( $\sim 66$-fold) and long drug retention time & {$[38]$} \\
\hline BSA-CK NPs & BSA & $\uparrow w a t e r$ solubility & [39] \\
\hline DCY51T-AuCKNps & AuNPs synthesized using Lactobacillus kimchicus & Drug loading efficiency-11.03\% & [40] \\
\hline CK:DA-OCMC NPs & CK:DA-OCMC at different ratios 1:10, 2:10, 3:10 & $\begin{array}{c}\uparrow \text { water solubility } \\
\uparrow E E \% \text { from } 20.2 \pm 1.4 \text { to } 42.6 \pm 1.2 \% \\
\uparrow \text { drug loading capacity from } 3.0 \pm 0.2 \text { to } 10.6 \pm 1.4 \% \text { by } \uparrow \text { drug: carrier ratio } \\
\text { Enhanced cellular uptake and increased cytotoxicity than CK }\end{array}$ & [41] \\
\hline GK-OCMC NPs & GK: OCMC at different ratios of 1:10, 2:10, 3:10 & $\begin{array}{c}\uparrow \text { water solubility and permeability } \\
\uparrow E E \% \text { from } 5.9 \pm 1.2 \text { to } 20.8 \pm 2.5 \% \\
\uparrow \text { drug loading capacity from } 1.9 \pm 1.8 \text { to } 4.2 \pm 0.7 \% \text { by } \uparrow \text { drug: carrier ratio } \\
\text { Enhanced cellular uptake and increased cytotoxicity than CK }\end{array}$ & {$[42]$} \\
\hline APD-CK micelles & $\begin{array}{c}\text { CK: A54-PEG-DA-OCMC at different ratios of } 1: 20, \\
2: 20,4: 20\end{array}$ & $\begin{array}{c}\uparrow E E \% \text { increased from } 61.7 \pm 1.4 \text { to } 76.5 \pm 1.2 \% \\
\uparrow \text { drug loading capacity from } 1.6 \pm 0.1 \text { to } 3.1 \pm 1.4 \% \text { by } \uparrow \text { drug: carrier ratio }\end{array}$ & [43] \\
\hline
\end{tabular}

CK, compound K; CyD, cyclodextrin; GCKT, ginsenoside CK with TPGS; TPGS, D- $\alpha$-tocopheryl polyethylene glycol 1000 succinate; EE, encapsulation efficiency; PEG, polyethylene glycol; PCL, polycaprolactone; AP, ascorbyl palmitate; P-gp, P-glycoprotein; PC, phosphatidylcholine; DP, 1,2-distearoyl-sn-glycero-3-phosphoethanolamine polyethylene glycol 2000; BSA, bovine serum albumin; NPs, nanoparticles; OCMC, O-carboxymethyl chitosan; DA, deoxycholic acid. 
In a recent comparative study on CK and CK within OCMC NPs showed that the later had higher water solubility and membrane permeability [42]. Similarly, a recent study found that CK-loaded with A54-PEG-DA-OCMC, known as APD-CK micelles, enhanced the delivery of CK. A54 is a long peptide of 12 amino acids which binds explicitly to hepatic cancer cells. Drug release was pH-dependent, and its release at $\mathrm{pH} 7.4$ was slow $(32.69 \%)$ compared to a fast release $(73.49 \%)$ at $\mathrm{pH} 5.8$ [43].

\subsection{Safety}

As per the new clinical guidelines, drug safety tests should be screened with two animal types, inclusive of non-rodents (usually dogs) and rodents (mice or rats) [44]. For preclinical safety evaluation, rats and mice were assessed for acute and 26-week recurrent-dose toxicity of CK.

Single oral supplementation of CK for rats $(8 \mathrm{~g} / \mathrm{kg})$ and mice $(10 \mathrm{~g} / \mathrm{kg})$ did not induce toxicity or mortality in the same. On the other hand, for 26-week toxicity (e.g., clinical symptoms, biochemical and hematological parameters, urine analysis, the body weights, food consumption, and histopathology of rats) were evaluated at 13,40 , or $120 \mathrm{mg} / \mathrm{kg}$ doses of CK. The NOAEL (no observed adverse effect levels) doses were $40 \mathrm{mg} / \mathrm{kg}$ and $120 \mathrm{mg} / \mathrm{kg}$ for females and males, respectively. However, a decrease in body weight, fur-loss, reduced activity, and lack of energy were transiently observed in the $120 \mathrm{mg} / \mathrm{kg}$ male test group [45]. Oral preclinical safety of CK was evaluated on Beagle dogs $(4,12$, or $36 \mathrm{mg} / \mathrm{kg})$ for 26-weeks. The NOAEL dose for dogs was $12 \mathrm{mg} / \mathrm{kg}$ [46].

Considering clinical perspective, in a randomized, double-blind trial on healthy Chinese subjects, compared to placebo, the treatment group were orally administered CK at 100, 200, or $400 \mathrm{mg}$ doses for up to nine times a week. The results of this documented study showed the safety of CK during the intervention period [47]. However, it has been suggested that further evaluations are necessary to affirm the safety of $\mathrm{CK}$ administration in humans.

\section{Health-Promoting Activities}

Compound $\mathrm{K}$, in terms of its bioactivity, has gained much interest as a rarely known ginsenoside [48]. Investigation on the CK metabolism is beneficial to gain better insights into the pharmacological activities of CK. Concerning this, a recent study used an ultra-performance LC quadrupole time-of-flight tandem MS to characterize CK (oral dose $50 \mathrm{mg} / \mathrm{kg}$ ) in feces and urine of SD rats, resulting in the detection of tentative twelve (M1-M12) metabolites. The authors suggested sequential oxidation, deglycosylation and conjugation as the key metabolic pathways for CK metabolic profile characterization [49]. This section summarizes recent studies on various health-promoting activities of CK (Tables 3 and 4 and Figure 2).

\subsection{Hepatoprotective}

The hepatoprotective effects of CK were observed against the injury caused by carbon tetrachloride [50], tert-butyl hydroperoxide [51], paracetamol (acetaminophen) [52], or as in recent studies by sodium valproate (SVP) [9]. Compound K exhibited protective effects against hepatotoxicity caused by SVP via minimizing oxidative stress through triggering the hepatic antioxidant system and inhibiting lipid peroxidation [9]. Among other protecting effects, CK significantly improved liver fibrosis in a high-fat diet (HFD)-induced rats [53]. Another study evaluated the effect of CK on hepatosteatosis using a mouse model with diabetes and obesity. The beneficial effects against hepatosteatosis were described by reducing expressions of lipogenesis genes and upregulating expressions of genes involved in fatty acid oxidation through adenosine monophosphate-activated protein kinase (AMPK) phosphorylation [54]. 


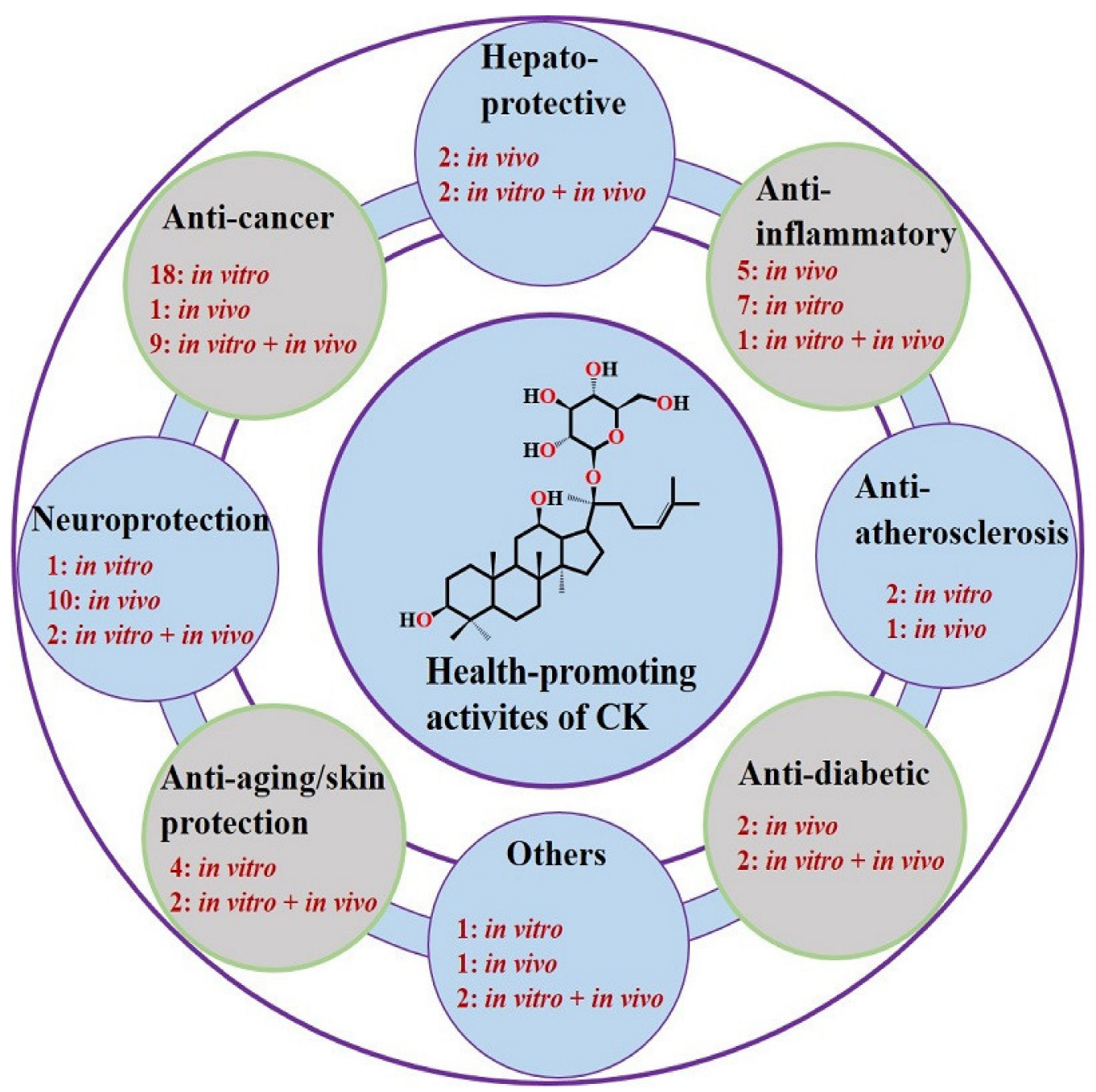

Figure 2. Schematic illustration of health-promoting activities of Compound K (CK). The numbers in the figure represent the total number of studies assessed for evaluating in vitro and in vivo, health-promoting activities of $\mathrm{CK}$. 
Table 3. Hepatoprotective, anti-inflammatory, anti-atherosclerosis, and anti-diabetic activities of CK and its derivatives.

\begin{tabular}{|c|c|c|c|c|c|}
\hline Material Type & ST & Model & Treatments & Major Findings & Ref. \\
\hline \multicolumn{6}{|c|}{ Hepatoprotective } \\
\hline CK & In vivo & SVP-induced SD rats & $\begin{array}{l}\text { LCK-80 mg/kg GCK + SVP } \\
\text { MCK-160 mg/kg GCK + SVP } \\
\text { HCK-320 mg/kg GCK + SVP } \\
\text { once daily for } 15 \text { days }\end{array}$ & $\begin{array}{c}\downarrow \text { hepatic index-LCK }(7.6 \%), \text { MCK }(8.7 \%) \text {, and HCK }(9.4 \%) \\
\downarrow \text { AST, ALT, ALP, TG and } \uparrow \text { ALB } \\
\uparrow \text { CAT, GPx, and SOD activities and GSH level } \\
\downarrow \text { MDA level and soluble epoxide hydrolase } \\
\text { (better with LCK) } \\
\uparrow \text { hepcidin level }\end{array}$ & [9] \\
\hline \multirow[t]{2}{*}{ CK and Rh1 } & In vivo & HFD-treated SD rats & $\begin{array}{l}\text { CK + phospholipid; phospholipid + Rh1; } \\
\text { phospholipid + CK }+ \text { Rh1 }(3 \mathrm{mg} / \mathrm{kg} / \text { day }) \\
1 \text { week }\end{array}$ & $\begin{array}{c}\text { Treatment either alone or in combined form (CK or Rh1) } \\
\downarrow \gamma \text {-GT, AST, ALT, ALP, TG, CHOL, FCHOL, LDL } \\
\uparrow \text { HDL levels } \\
\text { Anti-fibrotic effects by } \downarrow \text { expressions of TIMP-1, PC-I, } \\
\text { and PC-III } \\
\text { Improved insulin resistance by normalizing glucose levels }\end{array}$ & [53] \\
\hline & In vitro & $\begin{array}{l}\text { Rat liver stellate cell line } \\
\text { (HSC-T6) }\end{array}$ & CK, Rh1, CK+Rh1 for $6 \mathrm{~h}$ & $\begin{array}{c}\text { } \text { anti-proliferative effect } \\
\uparrow \text { apoptosis in HSC-T6 CK }(20.63 \%), \operatorname{Rh} 1(12.43 \%), \\
\text { CK+Rh1 }(18 \%)\end{array}$ & \\
\hline CK & In vivo & HFD-treated OLETF rats & CK (25 and $10 \mathrm{mg} / \mathrm{kg}), 12$ weeks & $\begin{array}{c}\downarrow \text { plasma glucose level and improved morphology of } \\
\quad \text { liver cells } \\
\downarrow \text { FAS and SREBP-1c expressions } \\
\uparrow \text { CPT- } 1 \text { and PPAR- } \alpha \text { expressions } \\
\uparrow \text { phosphorylation of AMPK }\end{array}$ & [54] \\
\hline CK from GBCK25 & In vivo & C57BL/6 mice & $\begin{array}{l}\text { GBCK } 25 \text { with CK (400, 200, 100, 20, } \\
\text { and } 10 \mathrm{mg} / \mathrm{kg} \text { ) once daily, } 12 \text { weeks }\end{array}$ & $\begin{array}{c}\downarrow \downarrow \text { liver weight } \\
\downarrow \text { inflammation, degree of steatosis, } \\
\text { and ballooning degeneration } \\
\downarrow \text { ALT, TC and TG levels } \\
\downarrow \text { TNF- } \alpha \text {, IL-1 } \beta \text {, IL-6 levels } \\
\downarrow \text { expressions of } \alpha \text {-SMA and TIMP-1 } \\
\text { Reduction in hepatic lipid accumulation and } \\
\downarrow \text { MDA levels } \\
\downarrow \text { FAS, ACC } \alpha \text { and CYP2E1 levels } \\
\downarrow \text { levels of p-JNK (reduced JNK activation) }\end{array}$ & [55] \\
\hline
\end{tabular}


Table 3. Cont.

\begin{tabular}{|c|c|c|c|c|c|}
\hline Material Type & ST & Model & Treatments & Major Findings & Ref. \\
\hline & In vitro & $\begin{array}{l}\text { Palmitic acid-treated } \\
\text { AML12 cells } \\
\text { LPS-treated RAW264.7 } \\
\text { cells } \\
\text { Kupffer cells }(\mathrm{KCs})^{*}\end{array}$ & $\begin{array}{l}\text { GBCK25 }(4,2 \text {, and } 1 \mu \mathrm{g} / \mathrm{mL}), 24 \mathrm{~h} \\
\operatorname{GBCK} 25(0.5,0.4, \text { or } 0.3 \mu \mathrm{g} / \mathrm{mL}), 24 \mathrm{~h}\end{array}$ & $\begin{array}{c}\downarrow \downarrow \text { cellular toxicity } \\
\downarrow \text { TG, FAS, ACC } \alpha \text { and CYP2E1 levels } \\
\downarrow \text { TNF- } \alpha, \text { IL-1 } \beta, \text { IL-6 in RAW264.7 and KC cells }\end{array}$ & \\
\hline \multicolumn{6}{|c|}{ Anti-inflammatory } \\
\hline CK & In vitro & $\begin{array}{l}\text { LPS-stimulated RAW264.7 } \\
\text { cells and HEK293 cells } \\
\text { transfected with } \\
\text { HA-AKT1, HA-Src, or } \\
\text { HA-AKT2 for } 48 \mathrm{~h}\end{array}$ & $\mathrm{CK}(10,5$, and $2.5 \mu \mathrm{M}), 24 \mathrm{~h}$ & $\begin{array}{c}\text { No effect on the viability } \\
\downarrow \text { expressions of TNF- } \alpha \text {, IL- } 1 \beta \text {, iNOS, and AOX1 } \\
\downarrow \text { phosphorylation of Akt1, not Akt2 }\end{array}$ & [2] \\
\hline BIOGF1K & In vitro & Pretreated RAW264.7 cells & $\begin{array}{l}\text { BIOGF1K }(200,100, \text { and } 50 \mu \mathrm{g} / \mathrm{mL}) \\
1 \mathrm{~h}+\mathrm{LPS}(1 \mu \mathrm{g} / \mathrm{mL}), 24 \mathrm{~h}\end{array}$ & $\begin{array}{c}\downarrow \text { NO production }(67 \%) \text { with BIOGF1K }(200 \mu \mathrm{g} / \mathrm{mL}) \\
\text { Significant scavenging of DPPH } \\
\downarrow \text { expressions of iNOS and IFN- } \beta \\
\downarrow \text { NF-kB activity (72\%), IRF3 pathway (63\%) } \\
\text { Inhibited IKK and TBK1 phosphorylation }\end{array}$ & [56] \\
\hline BIOGF1K & In vitro & Pretreated RAW264.7 cells & $\begin{array}{l}\text { BIOGF1K (30, 20, and } 10 \mu \mathrm{g} / \mathrm{mL}) \\
30 \mathrm{~min}+\mathrm{LPS}(1 \mu \mathrm{g} / \mathrm{mL}), 24 \mathrm{~h}\end{array}$ & $\begin{array}{c}\text { Dose-dependent } \downarrow \text { of NO and iNOS and } \\
\text { COX-2 expressions } \\
\text { AP-1 signaling pathway inhibited by blocking MAPKs } \\
\text { and MAPKKs }\end{array}$ & [57] \\
\hline BSA-CK NPs & In vitro & $\begin{array}{l}\text { Pretreated RAW } \\
264.7 \text { cells }\end{array}$ & $\begin{array}{l}\text { BSA-CK NPs and CK }(20,15,10,5 \text {, } \\
\text { and } 1 \mu \mathrm{M}), 1 \mathrm{~h}+\mathrm{LPS}(1 \mathrm{mg} / \mathrm{mL})\end{array}$ & $\begin{array}{c}\downarrow \text { NO production by BSA-CK NPs }(10 \mu \mathrm{M}) \text { compared } \\
\text { with CK }\end{array}$ & [39] \\
\hline SPIONs-CK & In vitro & $\begin{array}{l}\text { Pretreated RAW } \\
264.7 \text { cells }\end{array}$ & $\begin{array}{l}\text { SPIONs-CK and CK }(100,10, \\
\text { and } 1 \mu \mathrm{g} / \mathrm{mL}), 24 \mathrm{~h}+\mathrm{LPS}(1 \mu \mathrm{g} / \mathrm{mL}) \\
\text { Antioxidant- } 1 \text { to } 250 \mu \mathrm{g} / \mathrm{mL}\end{array}$ & $\begin{array}{l}\downarrow \text { NO production by CK and SPION-CK and inhibited } \\
\text { iNOS production by } 47.9 \%(\mathrm{CK}) \text { and } 45.8 \% \text { (SPION-CK) } \\
\qquad \text { (at } 10 \mu \mathrm{g} / \mathrm{mL}) \\
\downarrow \text { ROS production by SPIONs-CK and CK } \\
\text { Inhibition of DPPH was higher for SPIONs-CK }(72 \%) \\
\text { compared to CK }(21.1 \%) \text { at }(250 \mu \mathrm{g} / \mathrm{mL})\end{array}$ & [58] \\
\hline
\end{tabular}


Table 3. Cont.

\begin{tabular}{|c|c|c|c|c|c|}
\hline Material Type & ST & Model & Treatments & Major Findings & Ref. \\
\hline \multirow[t]{2}{*}{ CK } & In vivo & C57BL/6 mice & $\mathrm{CK}(20 \mathrm{mg} / \mathrm{kg}), 30 \mathrm{~h}$ & $\begin{array}{c}\uparrow \text { expression of SGLT1 gene and glucose uptake mediated } \\
\text { by SGLT1 }\end{array}$ & \multirow[t]{2}{*}{ [59] } \\
\hline & In vitro & Caco-2 cells & $\begin{array}{c}\mathrm{CK}(1,0.1,0.01, \text { and } 0.001 \mu \mathrm{M}), 12,24,36 \text {, } \\
\text { and } 48 \mathrm{~h}\end{array}$ & $\begin{array}{c}\uparrow \text { SGLT1 protein level dose-dependent } \\
\uparrow \text { SGLT1 protein level time-dependent } 1.70 \text { times }(24 \mathrm{~h}) \text { to } \\
2.01 \text { times }(48 \mathrm{~h}) \\
\uparrow \text { glucose uptake activity by } \uparrow \text { SGLT1 expressions }\end{array}$ & \\
\hline \multirow[t]{2}{*}{ CK } & \multirow[t]{2}{*}{ In vivo } & $\begin{array}{l}\text { Xylene-induced Kunming } \\
\text { mice with ear swelling }\end{array}$ & $\begin{array}{l}\mathrm{CK}(224,112,56,28,14, \text { and } 7 \mathrm{mg} / \mathrm{kg}) \\
\text { every day, } 5 \text { days }\end{array}$ & $\begin{array}{l}\text { CK displayed a dose-dependent inhibitory effect } \\
\text { At } 224 \mathrm{mg} / \mathrm{kg} \text { - maximum }(93.9 \%) \text { inhibition } \\
\text { Pain threshold induced by heat not effected }\end{array}$ & \multirow[t]{2}{*}{ [60] } \\
\hline & & $\begin{array}{l}\text { Carrageenan-induced } \\
\text { paw oedema SD rats }\end{array}$ & $\begin{array}{l}\text { CK }(160,80,40,20,10, \text { and } 5 \mathrm{mg} / \mathrm{kg}) \\
\text { orally every day, } 5 \text { days }\end{array}$ & $\begin{array}{c}\uparrow \text { rat inflammatory pain threshold significantly } \\
\downarrow \text { PGE2 level in the paw tissue, not in the gastric mucosa. } \\
\downarrow \text { COX-2 level in the gastric mucosa and paw tissue } \\
\text { Activities COX- } 1 \text { and }-2 \text { not effected }\end{array}$ & \\
\hline CK & In vivo & CIA-induced DBA/1 mice & $\begin{array}{c}\mathrm{CK}(224,56, \text { and } 14 \mathrm{mg} / \mathrm{kg}) \text { per day, } \\
21 \text { days }\end{array}$ & $\begin{array}{c}\text { Significant } \downarrow \text { in arthritis global assessment and swollen } \\
\text { joint count } \\
\uparrow \text { number of naïve T-cells and } \downarrow \text { activated T-cells and } \\
\text { DCs percentage } \\
\text { Inhibited migration and priming of DCs } \\
\downarrow \text { expressions of CD80, CD86, MHC II, and CCL } 21 \text { levels } \\
\text { (lymph nodes) }\end{array}$ & {$[61]$} \\
\hline CK & In vivo & $\begin{array}{l}\text { CIA-induced DBA/1 } \\
\text { OlaHsd mice }\end{array}$ & $\begin{array}{c}\text { CK }(100 \mu \mathrm{l}) \text { once a day }(20,10 \text {, and } \\
5 \mathrm{mg} / \mathrm{kg} / \text { day), } 6 \text { weeks (Preventive effect), } \\
4 \text { weeks (Therapeutic effect) }\end{array}$ & 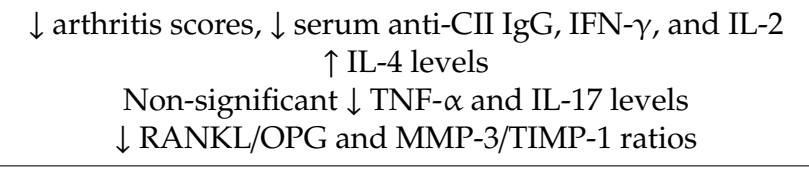 & [62] \\
\hline CK & In vivo & $\begin{array}{l}\text { Adjuvant-induced } \\
\text { arthritis }\end{array}$ & $\begin{array}{l}\text { CK }(160,40, \text { and } 10 \mathrm{mg} / \mathrm{kg}), \text { once daily, } \\
15 \text { days }\end{array}$ & 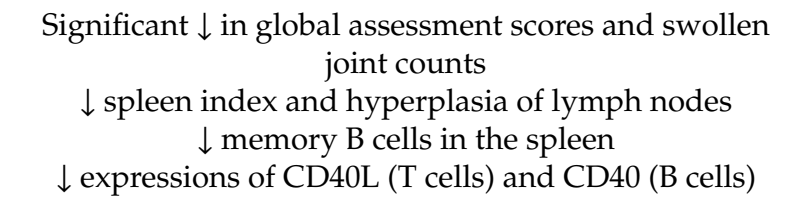 & [63] \\
\hline
\end{tabular}


Table 3. Cont.

\begin{tabular}{|c|c|c|c|c|c|}
\hline Material Type & ST & Model & Treatments & Major Findings & Ref. \\
\hline CK & In vivo & CIA-induced DBA/1 mice & CK (112 mg/kg/day), 24 days & 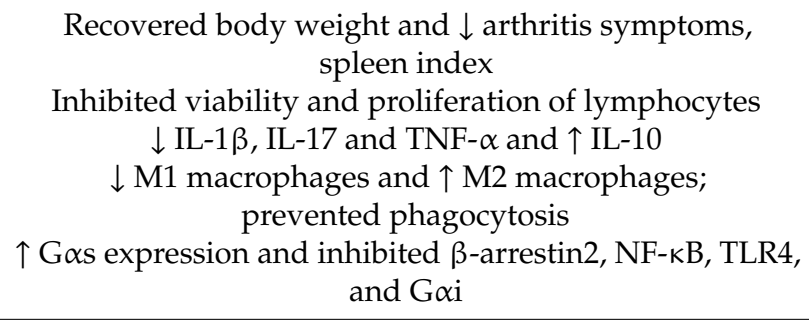 & [64] \\
\hline CK & In vitro & $\begin{array}{l}\mathrm{H}_{2} \mathrm{O}_{2} \text {-stimulated } \\
\text { MC3T3-E1 cells }\end{array}$ & $\begin{array}{l}\text { CK }(0.01-10 \mu \mathrm{M}) \text { with or without } \\
\qquad \mathrm{H}_{2} \mathrm{O}_{2}, 48 \mathrm{~h}\end{array}$ & $\begin{array}{c}\text { CK formed hydrogen bonds with IKK } \\
\uparrow \text { ALP activity, Col-I expressions, and mineralization } \\
\downarrow \text { ROS and NO production, IL-1 } \beta \text { expression }\end{array}$ & [65] \\
\hline GNP-CK-CopA3 & In vitro & LPS-activated RAW264.7 & $\begin{array}{c}\text { GNP-CK-CopA3 }(10-100 \mu \mathrm{g} / \mathrm{mL}) \\
1 \mathrm{~h}+\mathrm{LPS}(1 \mu \mathrm{g} / \mathrm{mL}), 24 \mathrm{~h}\end{array}$ & $\begin{array}{l}\text { NO production was inhibited (at } 20 \text { and } 40 \mu \mathrm{g} / \mathrm{mL}) \\
\text { ROS production inhibited-40.4\% }(20 \mu \mathrm{g} / \mathrm{mL}) \text { and } 65.05 \% \\
\qquad(40 \mu \mathrm{g} / \mathrm{mL}) \\
\downarrow \text { levels of TNF- } \alpha \text {, iNOS, COX-2, IL-6, and IL-1 } \beta \\
\text { Inhibited NF- } \kappa \mathrm{B} \text { and MAPK signaling pathways }\end{array}$ & [66] \\
\hline \multicolumn{6}{|c|}{ Anti-atherosclerosis } \\
\hline CK & In vivo & $\begin{array}{l}\text { ApoE-/- C57BL/6 } \\
\text { Peritoneal macrophages } \\
\text { from apoE-/- C57BL/6 }\end{array}$ & $\begin{array}{c}\text { CK }(9,3 \text {, and } 1 \mathrm{mg} / \mathrm{kg}) \text { one dose per day, } \\
8 \text { weeks. } \\
\text { ox-LDL }(100 \mu \mathrm{g} / \mathrm{mL})+\mathrm{CK}(30,10 \\
\text { and } 3.3 \mu \mathrm{M})\end{array}$ & $\begin{array}{c}\downarrow \text { atherosclerotic plaques (55\%) by activating } \\
\text { RCT pathway } \\
\downarrow \text { IL-6, IL-1 } \beta \text {, and TNF- } \alpha \text { levels } \\
\downarrow \text { cleaved IL-1 } \beta \text {, caspase-1, NLRP3, and NF-kB P65 } \\
\downarrow \text { inflammasome activity in mice and macrophages } \\
\downarrow \text { cholesterol ester (10 } \mu \mathrm{M} 46.21 \% \text { and } 30 \mu \mathrm{M} 60.24 \%)\end{array}$ & [67] \\
\hline $\begin{array}{l}\mathrm{CK} \text { and its } \\
\text { derivatives }\end{array}$ & In vitro & RAW264.7 cells & CK and CK derivatives $(30,10 \mu \mathrm{M})$ & $\begin{array}{c}\text { Structure } 1 \downarrow \text { cholesteryl ester contents in foam cells } \\
\text { compared to CK } \\
\uparrow \text { ABCA1 mRNA expression Structure } 1(319 \%) \text { compared } \\
\text { to CK }(151 \%) \\
\text { Structure } 1 \text { significantly activated LXR } \alpha \text { compared to CK } \\
\text { No effect on LXR } \beta \text { activation }\end{array}$ & [68] \\
\hline
\end{tabular}


Table 3. Cont.

\begin{tabular}{|c|c|c|c|c|c|}
\hline Material Type & ST & Model & Treatments & Major Findings & Ref. \\
\hline CK & In vitro & HUVECs & $\begin{array}{c}\text { Pretreated with CK } \\
(2.5,1.25, \text { and } 0.625 \mathrm{mM}), 12 \mathrm{~h}+\mathrm{ox}-\mathrm{LDL} \\
(80 \mathrm{mg} / \mathrm{mL}), 24 \mathrm{~h}\end{array}$ & $\begin{array}{c}\downarrow \text { expressions of IL-6, MCP-1, TNF- } \alpha \text {, VCAM1, } \\
\text { and ICAM-1 } \\
\downarrow \text { expression of caspase3, cleaved caspase-3 and } \\
\text { cytochrome c and LDH release } \\
\text { Reversed mitochondrial membrane depolarization } \\
\uparrow \text { Bcl2/Bax }\end{array}$ & [69] \\
\hline \multicolumn{6}{|c|}{ Anti-diabetic } \\
\hline \multirow[t]{2}{*}{ CK } & In vivo & HFD fed ICR mice & $\begin{array}{l}\text { Injected with STZ }(100 \mathrm{mg} / \mathrm{kg} \mathrm{BW}) \text { after } \\
4 \text { weeks + CK }(30 \mathrm{mg} / \mathrm{kg}), 4 \text { weeks }\end{array}$ & $\begin{array}{c}\downarrow \text { blood glucose levels, improve glucose tolerance } \\
\downarrow \text { PGC-1 } \alpha \text { expressions and inhibited PEPCK, } \\
\text { G6Pase expressions } \\
\text { Improved AMPK phosphorylation }\end{array}$ & {$[70]$} \\
\hline & In vitro & HepG2 cells & $\mathrm{CK}(8,4$, and $2 \mu \mathrm{M}), 24 \mathrm{~h}$ & $\begin{array}{l}\text { Dose-dependent inhibition of hepatic glucose production } \\
\downarrow \text { PEPCK protein level and } \uparrow \text { AMPK phosphorylation }\end{array}$ & \\
\hline $\mathrm{CK}$ and $\mathrm{Rb} 1$ & In vivo & $\begin{array}{l}\text { Epididymal adipose } \\
\text { tissue from ICR mice }\end{array}$ & $\begin{array}{l}\text { Glucose treatment (high concentration), } \\
24 \mathrm{~h}+\mathrm{CK}(10 \mu \mathrm{M}) \text { and } \mathrm{Rb} 1(10 \mu \mathrm{M})\end{array}$ & $\begin{array}{c}\downarrow \text { ROS production and ERS } \\
\downarrow \text { phosphorylation of PERK and IRE1a } \\
\downarrow \text { activation of NLRP3 inflammasome and } \downarrow \text { IL-1 } \beta \text {, } \\
\text { IL-6 production } \\
\downarrow \text { IRS-1 phosphorylation at a serine residue } \\
\uparrow \text { IRS-1 phosphorylation at tyrosine residue } \\
\uparrow \text { PI3K activity and Akt phosphorylation }\end{array}$ & [71] \\
\hline CD-CK conjugate & In vivo & $\begin{array}{l}\text { Alloxan-induced diabetic } \\
\text { zebrafish model }\end{array}$ & $\begin{array}{c}\text { CK and CD-CK }(15,10,7.5,5,2.5,1,0.5 \\
0.1, \text { and } 0.05 \mu \mathrm{M}), 2 \text { days }\end{array}$ & $\begin{array}{l}\text { Good recovery of pancreatic islets by CD-CK compared } \\
\text { to CK } \\
\text { CD-CK showed less toxic }\left(\mathrm{LC}_{50}=20.68 \mu \mathrm{M}\right) \text { than } \mathrm{CK} \\
\left(\mathrm{LC}_{50}=14.24 \mu \mathrm{M}\right)\end{array}$ & {$[72]$} \\
\hline
\end{tabular}


Table 3. Cont

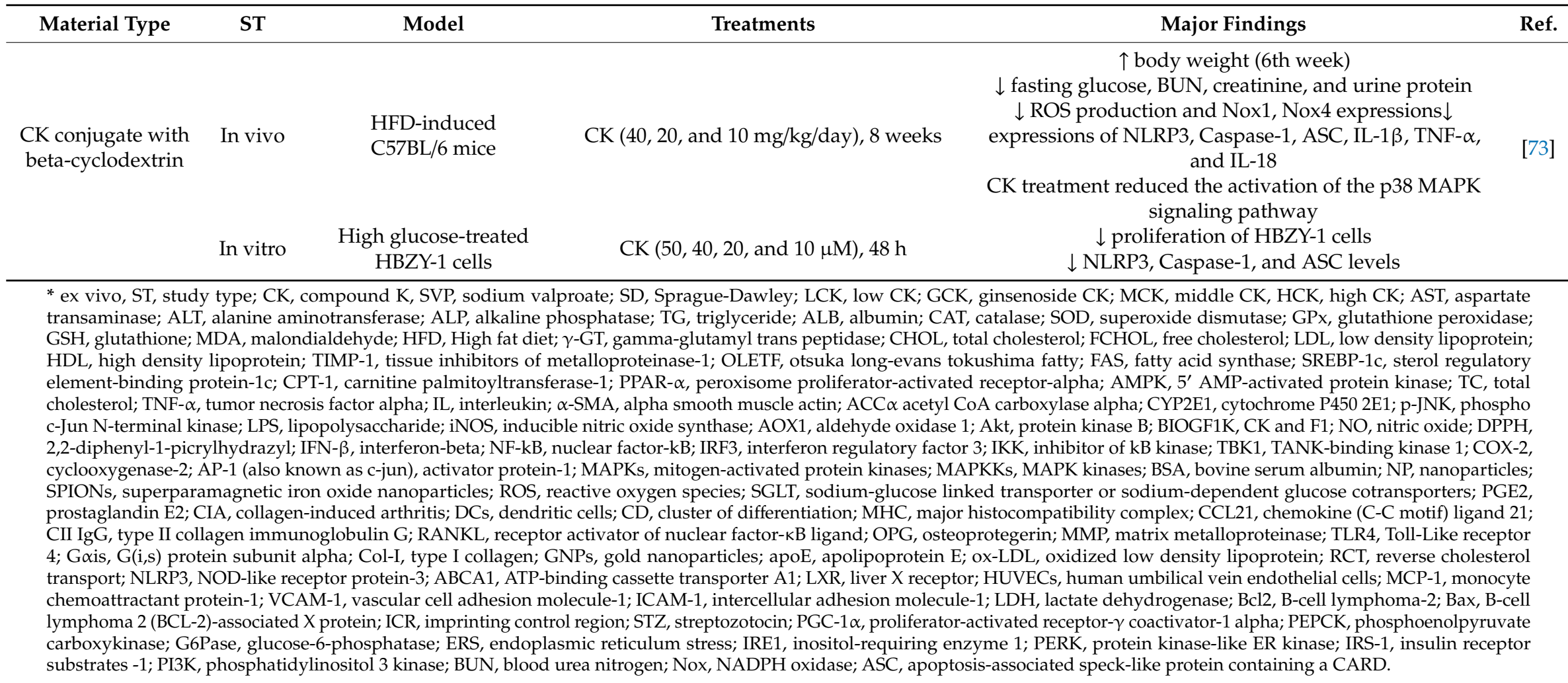


Similarly, Choi et al. showed the ameliorating effects of GBCK25 (fermented ginseng, rich in CK) on nonalcoholic steatohepatitis (NASH). They found that GBCK25 was capable of downregulating cytochrome P450 2E1 (CYP2E1) levels alongside reduced activation of cellular c-Jun N-terminal kinase (JNK) [55]. These findings indicate that CK can be used for liver disease prevention and/or treatment.

\subsection{Anti-Inflammatory}

From previous studies, the anti-inflammatory activity of CK was ascribed to decreased synthesis of pro-inflammatory cytokines ((interleukin (IL)-6, IL-1 $\beta$, and tumor necrosis factor-alpha (TNF- $\alpha$ )), cyclooxygenase-2 (COX-2), and inducible nitric oxide synthase (iNOS) [11]. However, recent studies have strengthened our understanding of the mechanistic implications at molecular and cellular levels (Table 3). In one study, CK attenuated NF- $\mathrm{kB}$ by modulating the Akt1-mediated inflammatory gene expression in LPS-induced macrophages [2]. Compound K-rich fraction (BIOGF1K), consisted of $3.2 \mathrm{~g}$ of $\mathrm{CK}$ and $1.5 \mathrm{~g}$ of saponin F1, and was examined for its anti-inflammatory activity. Compound K-rich fraction has down-regulated LPS-stimulated nitric oxide (NO) production in RAW264.7 cells. Furthermore, expressions of iNOS and IFN- $\beta$ were reduced by suppressing stimulation of NF- $\mathrm{kB}$ and interferon regulatory factor 3 , respectively. The inhibitory mechanism of BIOGF1K was due to the blockage of an inhibitor of $\mathrm{kB}$ kinase (IKK) and TANK-binding kinase 1 (TBK1), leading to reduced production of NO and IFN- $\beta$ [56]. Likewise, in another study BIOGF1K inhibited COX-2 and iNOS mRNA expressions in LPS-induced RAW264.7 cells. Mechanistically, BIOGF1 K blocked activation of activator protein-1 (AP-1) pathway by targeting mitogen-activated protein kinases (MAPKs) such as ERK (extracellular signal-regulated kinase) and p38, and MAPK kinases (MAPKKs) such as MAPK/ERK kinase 1/2 and MAPK kinase 3/6 [57]. Together, these findings indicate that BIOGF1 $\mathrm{K}$ plays a protective role in macrophage-mediated inflammatory responses. In addition, the use of CK as BSA-CK NPs [39] and CK-conjugated superparamagnetic iron oxide nanoparticles [58], has been shown to have anti-inflammatory activity against RAW 264.7 cells induced by LPS. In another study, CK-mediated modulation of sodium/glucose cotransporter one via the epidermal growth factor receptor (EGFR) pathway was found to reduce intestinal inflammation [59].

Inflammation commonly follows pain. In this line, the effect of CK on inflammation and pain was represented using in vivo models of xylene-induced ear swelling, and paw oedema stimulated with carrageen. The anti-inflammatory and pain-reducing effects of CK were due to the decreased production of prostaglandin E2 by downregulating COX-2 expression (Table 3) [60]. Referring to arthritis, the attenuating role of $\mathrm{CK}$ has been shown by inhibiting the production of inflammatory cytokines, suppressing T-cell activation, inhibiting the multiplication of B-cells, macrophages regulation, and reducing the level of autoantibodies [11]. Among T cells, the potential mechanism of CK treatment involves suppression of dendritic cells (DCs) priming of T-cell activation, suppression of chemokine CCL21 (with receptor CCR7) associated with DC movement and signaling between T cells and DCs in collagen-induced arthritis animal model. Notably, a positive correlation $\left(R^{2}=0.9830\right.$, $p=0.0009$ ) was found in percentages of activated T-cells and DCs, while a negative correlation $\left(\mathrm{R}^{2}=0.8348, p=0.03\right)$ in percentages of naïve T cells and DCs [61]. In another study, CK suppressed humoral immune response of T helper type 1 (Th1) cells and significantly suppressed expressions of matrix metalloproteinases (MMP)-3 and-13 and receptor activator of NF- $\mathrm{KB}$ ligand (RANKL) [62]. Concerning effects on B cells, CK was described as reducing the percentage of memory B cells. Authors suggested that the reduction in memory B cells may be dependent upon T-cells [63]. Previously, CK displayed anti-arithic effects on multifunctional macrophages by reducing the development of pro-inflammatory cytokines. In a recent study, however, the function of CK was shown to inhibit $\beta$-arrestin2, thus hindering the transition of macrophages from type M1 to type M2 [64]. The protective role of CK was also reported against osteoarthritis using in vitro and silico studies. Compound $\mathrm{K}$ displayed high binding affinity to a cytokine-activated kinase (IKK) compared to other ginsenosides as revealed in the molecular docking analysis. Thus, the anti-osteoarthritic effect of CK was due to inhibition of IKK activity in vitro [65]. Interestingly, in a recent study, GNPs 
were made intracellularly using Gluconacetobacter liquefaciens kh-1 (a probiotic strain) and used for synthesizing peptide (CopA3) conjugated nanoparticle (GNP-CK-CopA3) hybrids. Compound K, as peptide-nanoparticle hybrids showed anti-inflammatory effects by inhibiting the activation of NF-kB and MAPK signaling pathways [66].

\subsection{Anti-Atherosclerosis}

Atherosclerosis is well known to be an inflammatory disease; the anti-inflammatory effects of CKare more or less directly linked to its anti-atherogenic effects. In terms of anti-atherosclerosis, an important feature of CK was found to be associated with liver X receptor alpha ( $\mathrm{XXR} \alpha)$ (Table 3). Targeting $\mathrm{LXR} \alpha$, a study showed that $\mathrm{CK}$ treatment resulted in a dose-dependent reduction of atherosclerotic plaques by activating the reverse cholesterol transport (RCT) pathway, reducing inflammatory cytokines, and inhibition of inflammasome activity with LXR activation in apoE-/- C57BL/6 mice. Compound K triggered the RCT pathway by upregulating ATP-binding cassette transporter (ABC) A1, ABCG1, LXR $\alpha$, ABCG5, and ABCG8. In addition, CK supplementation increased the cholesterol efflux and reduced the inflammasome activity in peritoneal macrophages of mice [67]. Another research demonstrated the use of CK and its derivatives in the activation of $\mathrm{LXR} \alpha$. The study documented the synthesis of six CK derivatives by adding short-chain fatty acids into the carbohydrate chain of CK at different locations. Effects on the foam cell model were evaluated, and the biological activities of all derivatives were found to be at par or better than their parent CK. All derivatives were capable of activating LXR $\alpha$. Compound $\mathrm{K}$ derivative 1 displayed the best potency amongst all [68].

Similarly, it was found that the CK prevents inflammation and apoptosis in human umbilical vein endothelial cells, induced through oxidized low-density lipoprotein (ox-LDL). In endothelial cells, lectin-like oxidized low-density lipoprotein receptor-1 (LOX-1) uptakes ox-LDL leading to pro-inflammatory effects. Compound K decreased LOX-1 expression and inhibited the nuclear translocation of NF-kB, and phosphorylation of JNK and p38 [69]. The results indicate that CK [67,69] and its derivatives [68] have the anti-atherosclerosis effect.

\subsection{Anti-Diabetic}

Ginsenosides play an important anti-diabetic role by modulating insulin resistance, regulating lipid and glucose metabolism, protecting from the inflammatory response, and oxidative stress. In this line, a study showed that CK administration suppressed liver gluconeogenesis by inhibiting glucose-6-phosphatase and phosphoenolpyruvate carboxykinase expressions in HFD-fed ICR mouse model and HepG2 cell line. Meanwhile, the expressions of hepatocyte nuclear factor 4 alpha, peroxisome proliferator-activated receptor 1-alpha, and forkhead transcription factor $\mathrm{O} 1$ were decreased while AMPK phosphorylation was increased significantly [70]. Furthermore, the management of insulin resistance is essential for controlling diabetes. In this line, CK was found to be able to inhibit inflammation and modulate insulin resistance in adipose tissue by repressing the activation of NOD-like receptor family, pyrin-containing protein 3 (NLRP3) associated with endoplasmic reticulum stress (ERS) (Table 3) [71]. In another study, beta-cyclodextrin-conjugated CK ( $\beta$-CD) was used to modulate diabetes against an alloxan-induced zebrafish model. The recovery of affected pancreatic islets in CD-CK conjugate was significantly higher $\left(\mathrm{EC}_{50}=2.16 \mu \mathrm{M}\right)$ than in $\mathrm{CK}\left(\mathrm{EC}_{50}=7.22 \mu \mathrm{M}\right)[72]$. Furthermore, the protective effect of CK on diabetic nephropathy in HFD/ streptozotocin-induced mice has been demonstrated through significant reduction of oxidative stress and down-regulating expressions of NADPH oxidase (Nox)-1 and-4 proteins. Additionally, the reactive oxygen species (ROS)-mediated activation of the inflammasome assembly was reduced, and renal p38 MAPK phosphorylation was inhibited (Table 3) [73].

\subsection{Anti-Cancer}

The promising anti-cancer activity CK has been previously identified in various types of cell lines, including lung carcinoma, leukemia, breast cancer, colorectal cancer, prostate cancer, gastric 
carcinoma, nasopharyngeal carcinoma and pulmonary adenocarcinoma [11,74]. Among recent findings (Table 4), a study documented the suppressing effect of CK on COX-2 and Arg-1 genes linked to immunosuppression, apoptosis, and pro-inflammatory cytokines production by myeloid-derived suppressor cells (MDSCs) from the xenografted colorectal (CT26) cancer mice. Compound K could act as a promising therapeutic molecule by targeting MDSCs [75]. Another study elucidated the inhibitory action of CK on the development and metastasis of glioblastoma cell lines (U87MG and U373MG). The effects were due to cell cycle arrest, decreased cyclins (D1 and D3) levels, apoptosis through nuclear condensation, activation of apoptotic enzymes, increased production of ROS, and the depolarized potential of the mitochondrial membrane. The anti-proliferative effect was due to the blockage of the phosphatidylinositol three kinase (PI3K)/Akt signaling pathway in glioblastoma [76]. Likewise, CK was found to block glycogen synthase kinase $3 \beta$ signaling [77] and the PI3K/Akt signaling pathway [78] in breast cancer cells (MCF-7). Additionally, the combined CK and cisplatin had better effects than either molecule alone [78]. A later study gave in vivo evidence of CK's protecting effects against hormone-independent breast cancer by degrading cyclin D1 protein [79] (Table 4). Recently, Li et al. synthesized ester derivatives $(1 c, 2 c, 3 c)$ of $M 1$, and found that among all, compounds $2 c, 3 c$ had an effective growth inhibitory effect on MCF-7 cells [80]. Another study shed light on the biological mechanism of CK against breast cancer using SKBR3 cells. Compound $\mathrm{K}$ displayed anti-cancer effects in SKBR3 cells by enhancing apoptosis through downregulation of Akt-1. In addition, CK was found to reduce invasion and metastasis [81].

Compound $\mathrm{K}$ inhibited proliferation, augmented autophagy, and apoptosis of non-small cell lung cancer (NSCLC) (A549 and H1975) cells through the mammalian target of rapamycin (mTOR)/AMPK and JNK signaling pathways (Table 4) [82]. Furthermore, the suppression of the growth of NSCLC cells was studied by targeting the metabolism of glucose. Compound $\mathrm{K}$ suppressed the levels of hypoxia-inducible factor 1-alpha and its downstream glucose transporter1 gene [83]. Another study showed the anti-cancer effect of CK against HepG2 cells and xenografted (HepG2) BALB/c nude mice. Compound $\mathrm{K}$ resulted in cell cycle arrest, blocked cell cycle progression, and apoptosis induction by modulating B-cell lymphoma $2(\mathrm{Bcl} 2)$ to $\mathrm{Bcl} 2$ associated $\mathrm{X}$ (an apoptosis regulator) ratio in HepG2 cells. Furthermore, a substantial reduction in tumor proliferation was observed in the CK-supplemented mice group [84]. Also, CK induced apoptosis and ERS in liver cancer cells and xenografted mice by modulating signal transducers and activators of transcription-3 (STAT3) activation [85]. Another study showed for the first time that CK targeted annexin A2, which leads to inhibition of NF- $K B$ [86]. Compound $\mathrm{K}$ enhanced ERS and calcium release by ryanodine receptors leading to apoptosis in lung cancer cells of humans. In particular, the use of an ER stress inhibitor (4-phenylbutyrate) enhanced CK- mediated apoptosis [87]. Another research provided the first proof that the CK usage results in the TNF-related apoptosis-inducing ligand (TRAIL) sensitization in TRAIL-resistant HT-29 cells and potentiated TRAIL-stimulated apoptosis in HCT116 by autophagy-linked death receptor (DR) 5 stimulation. The upregulated expression of DR5 was dependent upon ROS mediated JNK-autophagy-activation and CCAAT/enhancer-binding protein (C/EBP) homologous protein/p53 pathway (autophagy-independent) [88]. In neuroblastoma cells, CK enhanced ROS-linked apoptosis and impaired the autophagic flux. In addition, CK with chloroquine (combination approach) stimulated apoptosis in cell line and mouse models and may, therefore, be a potential approach for treating neuroblastoma [16]. The protective role of CK was also investigated against glioma (inveterate brain tumor). Compound $\mathrm{K}$ was observed to inhibit the stromal cell-derived growth factor 1 migration of $\mathrm{C6}$ glioma cells by controlling protein kinase C alpha, ERK1/2, and MMP signaling molecules (Table 4) [89]. Recent studies showed the bioactivity of CK against human osteosarcoma cell (MG63 and U2-OS) lines. 
Table 4. Anti-cancer, neuroprotection, anti-aging/skin protection, and other activities of CK and its derivatives.

\begin{tabular}{|c|c|c|c|c|c|}
\hline Material & ST & Model & Treatments & Major Findings & Ref. \\
\hline \multicolumn{6}{|c|}{ Anti-cancer } \\
\hline CK & In vivo & $\begin{array}{l}\text { Balb/c mice with CT26 } \\
\text { tumor cells }\end{array}$ & & $\begin{array}{l}\downarrow \text { expression of Cox- } 2 \text { and Arg- } 1 \\
\downarrow \text { productions of IL-1 } 1 \beta, \text { IL-6, and IL-17 } \\
\downarrow \text { CT26 tumor growth }\end{array}$ & {$[75]$} \\
\hline CK & In vitro & $\begin{array}{l}\text { U87MG and U373MG } \\
\text { cells }\end{array}$ & $\mathrm{CK}(50,20$, and $10 \mu \mathrm{M}), 72 \mathrm{~h}$ & $\begin{array}{c}\text { Significant growth reduction of target cells and inhibited cells mobility } \\
\text { and invasion } \\
\text { G0/G1 phase arrest for U87MG }(80.7 \%) \text { and U373MG }(77.3 \%) \\
\uparrow \begin{array}{c}\text { apoptosis } \\
\text { Negative regulation of PI3K/Akt/mTOR signaling pathway }\end{array}\end{array}$ & {$[76]$} \\
\hline CK & In vitro & MCF-7 cells & $\begin{array}{c}\mathrm{CK}(70,50,30 \text {, and } 10 \mu \mathrm{M}), \\
24 \mathrm{~h}\end{array}$ & $\begin{array}{l}\text { Inhibited proliferation dose-and time-dependently } \\
\downarrow \text { expressions of GSK3 } \beta \text {, cyclin D1, and } \beta \text {-catenin }\end{array}$ & {$[77]$} \\
\hline CK & In vitro & MCF-7 cells & $\begin{array}{l}\text { CK }(50 \mathrm{mmol} / \mathrm{L}) \text { or cisplatin } \\
(10 \mathrm{mg} / \mathrm{L}) \text {, alone or in } \\
\text { combination, } 24-96 \mathrm{~h}\end{array}$ & $\begin{array}{c}\text { Anti-proliferation activity: CK }(19.18 \pm 2.25) \text {, cisplatin }(21.34 \pm 2.84) \text {, } \\
\text { and both }(43.37 \pm 5.62) \\
\uparrow \text { apoptosis in the combined treatment compared to } \\
\text { individual treatments }\end{array}$ & [78] \\
\hline \multirow[t]{2}{*}{ CK } & In vivo & Xenograft nude mice & $\begin{array}{l}\text { CK }(1 \text { or } 0.2 \mathrm{mg} / \mathrm{kg}) \text {, every } \\
\text { other day, } 3 \text { weeks }\end{array}$ & Reduction in the tumor weight & [79] \\
\hline & In vitro & $\begin{array}{l}\text { MCF10DCIS.com and } \\
\text { MCF10CA1a }\end{array}$ & $\begin{array}{c}\mathrm{CK}(20,10 \mu \mathrm{M}), 24,48 \text {, and } \\
72 \mathrm{~h}\end{array}$ & $\begin{array}{l}\quad \downarrow \text { viability in dose-and time-dependently } \\
\quad \uparrow \text { cell cycle blockage } \\
\downarrow \text { cyclin D1 production and } \uparrow \text { cyclin D1 degradation }\end{array}$ & \\
\hline $\begin{array}{l}\text { M1 and its } \\
\text { derivatives }\end{array}$ & In vitro & $\begin{array}{l}\text { MCF-7 and } \\
\text { MDA-MB-231 cells }\end{array}$ & $\begin{array}{l}\mathrm{M} 1,1 \mathrm{c}, 2 \mathrm{c} \text {, and } 3 \mathrm{c}(100,50,25 \\
\text { and } 1 \mu \mathrm{M})\end{array}$ & $\begin{array}{c}\text { Derivatives 2c and 3c showed good inhibitory effects } 80 \% \text { inhibition for } \\
\text { MCF-7 (lower con.) } \\
\text { For MDA-MB-231, better effects on higher concentration } \\
\text { Derivatives 2c and 3c changed membrane permeability and promoted } \\
\text { apoptosis of MCF-7 }\end{array}$ & [80] \\
\hline CK & In vitro & SKBR3 cells & $\mathrm{CK}(0-50 \mu \mathrm{M}), 3-24 \mathrm{~h}$ & $\begin{array}{c}\uparrow \text { anti-proliferative and apoptotic activities } \\
\uparrow \text { levels of cleaved caspase- } 7,-8 \text {, and caspase-9 } \\
\downarrow \text { Bcl } 2 \text { levels and AKT- } 1 \text { levels, no effect on AKT-2 levels }\end{array}$ & {$[81]$} \\
\hline
\end{tabular}


Table 4. Cont.

\begin{tabular}{|c|c|c|c|c|c|}
\hline Material & ST & Model & Treatments & Major Findings & Ref. \\
\hline CK & In vitro & A549 and H1975 & $\mathrm{CK}(20 \mu \mathrm{g} / \mathrm{mL}), 24 \mathrm{~h}$ & 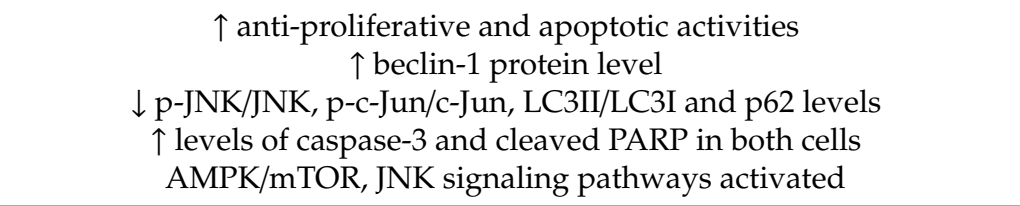 & [82] \\
\hline CK & In vitro & NSCLC & & $\begin{array}{l}\text { Dose-dependent anti-proliferative effect } \\
\text { Inhibited expression of PDK1, HK II, and LDHA } \\
\text { Inhibited expressions of HIF-1 } \alpha \text { and GLUT1 }\end{array}$ & [83] \\
\hline CK & In vivo & Xenografted BALB/c mice & $\begin{array}{l}\text { CK }(10 \mathrm{mg} / \mathrm{kg} / \text { day }) \\
\mathrm{CK}(20,10,5 \text {, and } 2.5 \mu \mathrm{mol} / \mathrm{L}) \\
48 \mathrm{~h}\end{array}$ & $\begin{array}{c}\text { Reduced tumor volume and } \downarrow \text { tumor weight }(49.4 \%) \\
\downarrow \text { viabilities of HepG2 cells in dose-and time-dependently and } \uparrow \text { apoptosis } \\
\uparrow \text { cell arrest at } 5 \mu \mathrm{mol}(68.61 \pm 2.91 \%) \text { and } 10 \mu \mathrm{mol}(178.29 \pm 2.57 \%) \\
\downarrow \text { expressions of cyclin D1 and CDK-4 } \\
\uparrow \text { expressions of cleaved-caspase- } 3,-9, \text { Bax, p21 }{ }^{\text {Cip } 1} \text { and p27Kip1 } \\
\downarrow \text { Bcl-2 and PARP (inactive) }\end{array}$ & [84] \\
\hline \multirow[t]{2}{*}{ CK } & In vivo & $\begin{array}{l}\text { SMMC-7721 cells injected } \\
\text { BALB/c nude mice }\end{array}$ & $\begin{array}{c}\mathrm{CK}(20,10, \text { and } 5 \mathrm{mg} / \mathrm{kg} / \text { day }) \\
15 \text { days }\end{array}$ & $\begin{array}{c}\text { Dose-dependent inhibition of tumor } \\
\text { Significant } \downarrow \text { in body weight of mice }(20 \mathrm{mg} / \mathrm{kg}) \\
\downarrow \text { p-STAT3 levels }\end{array}$ & \multirow[t]{2}{*}{ [85] } \\
\hline & In vitro & HepG2 and SMMC-7721 & $\mathrm{CK}(60,40$, and $20 \mu \mathrm{M}) 48 \mathrm{~h}$ & $\begin{array}{c}\text { } \text { apoptosis and ERS in cell lines } \\
\downarrow \begin{array}{l}\downarrow \text { DNA-binding ability of STAT3 } \\
\downarrow \text { p-STAT3 levels }\end{array} \\
\text { †ERS markers (CHOP and GRP78) expressions } \\
\text { PERK and IRE1 signaling pathways activated }\end{array}$ & \\
\hline CK & In vitro & HepG2 cells & CK $(6 \mu \mathrm{M}), 12 \mathrm{~h}$ & $\begin{array}{c}\downarrow \text { interaction and of colocalization (nucleus) of p50 and annexin A2 } \\
\text { NF- } \kappa \text { B signaling pathways activation inhibited and } \\
\downarrow \text { downstream genes expressions }\end{array}$ & [86] \\
\hline CK & In vitro & A549 and SK-MES-1 & $\begin{array}{c}\mathrm{CK}(15,10, \text { and } 5 \mu \mathrm{M}), 48 \mathrm{~h} \\
\text { and } 15 \mu \mathrm{M}, 6,12,24,36 \\
\text { or } 48 \mathrm{~h}\end{array}$ & $\begin{array}{c}\mathrm{IC}_{50} \text { for viabilities of A549 }(17.78 \mu \mathrm{M}) \text { and SK-MES-1 }(16.53 \mu \mathrm{M}) \\
\text { 个 caspase } 12 \text { dependent apoptosis } \\
\text { Induced ERS by } \uparrow \text { p-eIF2 } \alpha \text { expressions and protein levels of XBP-1S, } \\
\text { GRP78(BiP), and IRE1 } \alpha \\
\qquad \begin{array}{l}\text { intracellular calcium levels and m-calpain activities }\end{array}\end{array}$ & [87] \\
\hline
\end{tabular}


Table 4. Cont.

\begin{tabular}{|c|c|c|c|c|c|}
\hline Material & ST & Model & Treatments & Major Findings & Ref. \\
\hline CK & In vitro & HT-29 and HCT116 cells & CK $(50$ or $20 \mu \mathrm{M}), 24 \mathrm{~h}$ & $\begin{array}{c}\downarrow \text { expressions of Mcl-1, survivin, Bcl-2, XIAP, and cFLIP } \\
\uparrow \text { expressions of tBid, Bax, and cytochrome c, and DR5 } \\
\uparrow \text { in LC3-II and Atg7 levels and expressions of p53 and CHOP } \\
\uparrow \text { JNK phosphorylation }\end{array}$ & [88] \\
\hline \multirow[t]{2}{*}{ CK } & In vivo & $\begin{array}{l}\text { SK-N-BE(2) injected } \\
\text { BALB/c nude mice }\end{array}$ & $\begin{array}{l}\mathrm{CK}(30 \mathrm{mg} / \mathrm{kg}) \text { and } \\
\text { chloroquine }(50 \mathrm{mg} / \mathrm{kg}) \\
3 \text { times } / \text { week } / 60 \text { days }\end{array}$ & $\begin{array}{c}\uparrow \text { TUNEL-positive cells and caspase- } 3 \text { expression } \\
\text { Compared to chloroquine, CK and CK+ chloroquine significantly } \\
\text { reduced tumor size } \\
\uparrow \text { inhibition in the combination approach }\end{array}$ & \multirow[t]{2}{*}{ [16] } \\
\hline & In vitro & $\begin{array}{l}\text { SK-N-BE(2) and } \\
\text { SH-SY5Y cells }\end{array}$ & $\begin{array}{c}\mathrm{CK}(20,15,10,5 \text { and } 2 \mu \mathrm{M}) \\
24 \mathrm{~h}\end{array}$ & $\begin{array}{c}\uparrow \text { cell cycle arrest (at sub G1 phase), ROS production and P21 protein } \\
\text { level a } \\
\qquad \begin{array}{c}\uparrow \text { caspase-dependent apoptosis } \\
\text { Induced early phase autophagy by } \uparrow \text { BECN, Atg7, and LC3B expressions } \\
\text { Inhibited late phase autophagy }\end{array}\end{array}$ & \\
\hline CK & In vitro & $\begin{array}{l}\text { SDF-1 induced C6 } \\
\text { glioma cells }\end{array}$ & $\begin{array}{l}\mathrm{CK}(10,3,1,0.3,0.1 \\
\text { and } 0.03 \mu \mathrm{M}), 24 \mathrm{~h}\end{array}$ & $\begin{array}{l}\text { CK abridged scratch wound-healing and inhibited C6 cells migration } \\
\downarrow \text { phosphorylation of downstream targets PKC } \alpha \text { (SDF-1 pathway) and } \\
\text { ERK1/2 (CXCR4 pathway) }\end{array}$ & [89] \\
\hline CK & In vitro & MG63 and U2-OS cells & $\begin{array}{l}\mathrm{CK}(30,25,20,15,10, \\
\text { and } 5 \mu \mathrm{M}), 3 \text { days }\end{array}$ & $\begin{array}{c}\text { Anti-proliferative effect against osteosarcoma cells }\left(\mathrm{IC}_{50}=20 \mu \mathrm{M}\right. \\
\text { for } 3 \text { days }) \\
\uparrow \text { apoptosis rate CK }(20 \mu \mathrm{M}) \text { : U2-OS }(17.66 \pm 1.37 \%), \mathrm{MG}-63 \\
(24.16 \pm 2.25 \%) \\
\text { Suppressed invasion and migration } \\
\text { Blocked PI3K/mTOR/p70S6K1 signaling pathway } \\
\uparrow \mathrm{PTEN} \text { levels in both cells } \\
\downarrow \text { p-AKT and p-mTOR in both cells } \\
\downarrow \text { expressions of p-mTOR, p-mTOR/mTOR ratio and p70S6K1 in U2-OS } \\
\text { cells treated with RAD001 (mTOR inhibitor) }\end{array}$ & {$[90]$} \\
\hline \multirow[t]{2}{*}{ GCKT-liposomes } & In vivo & Athymic nude mice & $\begin{array}{c}\text { GCK }(15 \mathrm{mg} / \mathrm{kg}) \\
\text { GCKT-liposomes }(15 \mathrm{mg} / \mathrm{kg}) / \\
5 \text { times every } 3 \text { days }\end{array}$ & $\begin{array}{l}\text { GCKT-liposomes group, } \downarrow \text { mean tumor size from } 219.0 \pm 17.0 \mathrm{~mm}^{3} \text { to } \\
45.8 \pm 3.2 \mathrm{~mm}^{3} \\
\text { slow } \uparrow \text { in body weight in the initial days later no change }\end{array}$ & \multirow[t]{2}{*}[33]{} \\
\hline & In vitro & A549 & $\begin{array}{l}\text { GCK + GCKT-liposomes } \\
\text { different concentrations, } 24 \mathrm{~h}\end{array}$ & $\begin{array}{l}\mathrm{IC}_{50}, \mathrm{GCKT} \text {-liposomes }(16.3 \pm 0.8 \mu \mathrm{g} / \mathrm{ml}) \text { and CK }(24.9 \pm 1.0 \mu \mathrm{g} / \mathrm{ml}) \\
\text { No cytotoxicity to A549 with T-liposomes alone }\end{array}$ & \\
\hline
\end{tabular}


Table 4. Cont.

\begin{tabular}{|c|c|c|c|c|c|}
\hline Material & ST & Model & Treatments & Major Findings & Ref. \\
\hline \multirow[t]{2}{*}{$\begin{array}{c}\text { CK-M } \\
\text { (TPGS/PEG-PCL }\end{array}$} & $\begin{array}{l}\text { In vivo } \\
+\mathrm{CK})\end{array}$ & Male athymic nude mice & $\begin{array}{l}\text { CK and CK-M (15 mg/kg) } \\
\text { once every } 3 \text { days, } 15 \text { days }\end{array}$ & $\begin{array}{c}\text { Tumor volume after treatment CK-M }(2.67 \pm 0.88), \text { CK }(4.27 \pm 0.35) \\
\text { CK-M } \downarrow \text { tumor growth }(79.12 \pm 0.60 \text { to } 52.04 \pm 4.62 \%) \\
\text { Bodyweight: CK-M group }(25.02 \pm 2.42), \text { control }(22.83 \pm 1.83) \\
\text { low toxicity of CK-M to the mouse model }\end{array}$ & \multirow[t]{2}{*}{ [36] } \\
\hline & In vitro & A549 and PC-9 cells & $\begin{array}{c}\text { CK or CK-M }(100,50,25,12.5 \\
6.25, \text { and } 3.125 \mu \mathrm{g} / \mathrm{mL}), 24 \mathrm{~h}\end{array}$ & $\begin{array}{c}\mathrm{IC}_{50} \text { for A549: CK }(21.97 \pm 1.50 \mu \mathrm{g} / \mathrm{mL}) \text { CK-M }(25.43 \pm 2.18 \mu \mathrm{g} / \mathrm{mL}) \\
\mathrm{IC}_{50} \text { for PC-9: CK }(14.46 \pm 1.24 \mu \mathrm{g} / \mathrm{mL}) \text { CK-M }(18.35 \pm 1.90 \mu \mathrm{g} / \mathrm{mL}) \\
\uparrow C K-M \text { uptake by A549, PC-9 cells } \\
\uparrow \text { apoptosis } \\
\downarrow \text { inhibited tumor cell invasion and metastasis } \\
\text { Regulated Bcl-2, Bax, MMP-2, and Caspase-3 levels }\end{array}$ & \\
\hline \multirow[t]{2}{*}{ CK-AP/TPGS } & In vivo & Nude mice & $\begin{array}{l}\text { CK-AP/TPGS }(30 \mathrm{mg} / \mathrm{kg}) \\
\text { every } 3 \text { days until the } 12^{\text {th }} \text { day }\end{array}$ & $\begin{array}{l}\text { Maximum anti-tumor effect }(66.24 \pm 8.77 \%) \text { by CK mixed micelles at } \\
15 \text { th day } \\
\qquad \begin{array}{l}\text { low toxicity to kidney and liver } \\
\uparrow \text { apoptosis of tumor tissue } \\
\uparrow \text { Bax/Bcl-2 ratio }(7.25 \text {-times) } \\
\uparrow \text { cellular uptake and tumor targeting }\end{array}\end{array}$ & \multirow[t]{2}{*}{ [37] } \\
\hline & In vitro & A549 cells & $\begin{array}{l}\text { CK-AP/TPGS and CK }(80,40 \\
20,10, \text { and } 5, \mu \mathrm{g} / \mathrm{mL}, 24 \mathrm{~h}\end{array}$ & $\begin{array}{c}\text { CK mixed micelles had a better effect on cell cycle arrest at G0/G1 phase } \\
\text { than free CK } \\
\mathrm{IC}_{50} \text { for A549: free CK }(16.11 \pm 1.23 \mu \mathrm{g} / \mathrm{mL}) \text { and CK mixed micelles } \\
(10.29 \pm 1.1 \mu \mathrm{g} / \mathrm{mL}) \\
\uparrow \text { apoptosis, A549: CK mixed micelles }(45 \pm 5.25 \%) \text { and CK } \\
(17.28 \pm 2.25 \%)\end{array}$ & \\
\hline \multirow[t]{2}{*}{$\begin{array}{l}\text { CK PC/DP } \\
\text { micellar } \\
\text { system }\end{array}$} & In vivo & Xenografted nude mice & $\begin{array}{l}\text { CK or CK mixed micelles } \\
(30 \mathrm{mg} / \mathrm{kg}) \text { every } 3 \text { days for } \\
12 \text { consecutive days }\end{array}$ & $\begin{array}{c}\text { No damage to liver and kidney } \\
\text { Significant apoptosis of tumor tissue } \\
\uparrow \text { Bax/Bcl-2 ratio } \\
\uparrow \text { expressions of caspase- } 3,-8,-9 \text { and PARP }\end{array}$ & \multirow[t]{2}{*}{ [38] } \\
\hline & In vitro & A549 cells & $\begin{array}{l}\text { CK or CK mixed micelles } \\
\quad(12.15 \mu \mathrm{g} / \mathrm{mL}), 24 \mathrm{~h}\end{array}$ & $\begin{array}{c}\mathrm{IC}_{50} \text { for A549: CK }(18.31 \mu \mathrm{g} / \mathrm{mL}) \text { and CK mixed micelles }(12.15 \mu \mathrm{g} / \mathrm{mL}) \\
\text { Effective cell cycle arrest at G1 by CK PC/DP compared to CK } \\
\text { Highest apoptosis rate in CK PC/DP compared to CK }\end{array}$ & \\
\hline
\end{tabular}


Table 4. Cont.

\begin{tabular}{|c|c|c|c|c|c|}
\hline Material & ST & Model & Treatments & Major Findings & Ref. \\
\hline BSA-CK NPs & In vitro & $\begin{array}{l}\text { HaCaT, HepG2, A549, } \\
\text { HT29 cancer cells. LPS- } \\
\text { induced RAW264.7 cells }\end{array}$ & $\begin{array}{l}\text { CK and BSA-CK }(20,15,10,5 \\
\text { and } 1 \mu \mathrm{M}), 24 \mathrm{~h}\end{array}$ & $\begin{array}{c}\text { Improved anti-cancer ability of BSA-CK NPs compared to CK } \\
\text { Higher } \downarrow \text { in NO production by BSA-CK NPs }\end{array}$ & [39] \\
\hline $\begin{array}{l}\text { DCY51T } \\
\text { AuCKNps }\end{array}$ & In vitro & $\begin{array}{l}\text { A549, HT29, AGS and } \\
\text { RAW264.7 cells }\end{array}$ & $\begin{array}{c}\text { DCY } 51 \mathrm{~T} \text { AuCKNps } 0.1,1,5, \\
10,15, \text { and } 20 \mu \mathrm{M} \\
\text { Phototherapy- NPs+ AGS + } 1 \\
\text { or } 5 \mathrm{mg} / \mathrm{mL}, 24 \mathrm{~h}+\text { laser } \\
\text { at } 800 \mathrm{~nm}, 10 \mathrm{~min} .\end{array}$ & $\begin{array}{c}\uparrow \text { cytotoxicity for A549 and HT29 compared to CK } \\
\text { } \text { apoptosis after laser treatment in AGS }\end{array}$ & [40] \\
\hline $\begin{array}{l}\text { CK + chitosan } \\
\text { NPs }\end{array}$ & In vitro & HepG2 cells & $\begin{array}{l}\text { CK and CK-NPs }(3.125,6.25 \text {, } \\
12.5,25 \text {, and } 30 \mu \mathrm{g} / \mathrm{mL}), 24 \mathrm{~h}\end{array}$ & $\begin{array}{l}\text { At } 30 \mu \mathrm{g} / \mathrm{mL} \text {, the apoptotic cell percentage, CK }(39.02 \pm 0.42 \%) \text { and } \\
\text { CK-NPs }(47.57 \pm 1.65 \%)\end{array}$ & [41] \\
\hline $\begin{array}{l}\text { GK-OCMC } \\
\text { NPs }\end{array}$ & In vitro & PC3 cells & $\begin{array}{l}\text { CK and GK-OCMC NPs } \\
\qquad(30 \mu \mathrm{g} / \mathrm{mL})\end{array}$ & $\begin{array}{c}\uparrow \text { apoptosis by GK-OCMC treatment } \\
\uparrow \text { levels of caspase-3 }(29.93 \%) \text { and caspase- } 9(20.78 \%) \text { compared to } \\
\text { GK treatment. }\end{array}$ & [42] \\
\hline $\begin{array}{l}\text { APD-CK } \\
\text { micelles }\end{array}$ & In vitro & HepG2 and Huh-7 cells & $\begin{array}{c}\mathrm{CK}(30,20,10,5 \\
\text { and } 2.5 \mu \mathrm{g} / \mathrm{mL}), 24 \mathrm{~h} \text { and } 48 \mathrm{~h}\end{array}$ & $\begin{array}{l}\text { Time-dependent and dose-dependent cytotoxic effects of APD-CK } \\
\text { Texpressions of PARP, caspase-3, and -9 in HepG2 cells by } \\
\text { APD-CK micelles }\end{array}$ & [43] \\
\hline \multirow{2}{*}{$\begin{array}{l}\text { Parthenolide/ } \\
\text { CK tLyp-1 } \\
\text { liposomes }\end{array}$} & In vivo & Nude mice & $5 \mathrm{mg} / \mathrm{kg}, 24 \mathrm{~h}$ & $\begin{array}{l}\text { Strong tumor inhibition with parthenolide/ CK tLyp-1 liposomes } \\
\text { than combined }\end{array}$ & \multirow[t]{2}{*}[91]{} \\
\hline & In vitro & A549 & $\begin{array}{l}\text { Parthenolide }(1.5 \mu \mathrm{g} / \mathrm{mL})+ \\
\mathrm{CK}(30 \mu \mathrm{g} / \mathrm{mL}) \text { in } 5: 1 \text { ratio }\end{array}$ & $\begin{array}{c}\uparrow \text { mitochondrial apoptosis: CK }(8.2 \%) \text {, parthenolide }(11.8 \%), \mathrm{CK}+ \\
\text { parthenolide }(34.7 \%) \text {, Parthenolide/ CK tLyp-1 liposomes }(56.7 \%) \\
\uparrow \text { ROS levels: CK }(3.7 \%) \text {, parthenolide }(5.8 \%), \text { CK+ parthenolide }(24.6 \%) \text {, } \\
\text { Parthenolide/ CK tLyp-1 liposomes ( } 28.7 \%) \\
\text { Marked structural changes in mitochondria and impaired mitochondrial } \\
\text { membrane potential }\end{array}$ & \\
\hline CKGal & In vitro & $\begin{array}{l}\text { AGS, B16F10, HeLa, and } \\
\text { U87MG }\end{array}$ & $\begin{array}{l}\text { CKGal, CK, F12, and Rh2 } \\
\text { each at }(200,100,50,25,12.5 \text {, } \\
\quad 6.25 \mu \mathrm{mol}), 72 \mathrm{~h}\end{array}$ & $\begin{array}{c}\downarrow \text { cell viability: U87MG (13.7\%), AGS (8.7\%), B16F10 (2.6\%), } \\
\text { and HeLa (7.3\%) } \\
\begin{array}{c}\left.\text { IC }_{50} \text { CKGal: HeLa (40.38 } \mu \mathrm{mol}\right), \text { U87MG }(40.38 \mu \mathrm{mol}), \mathrm{B} 16 \mathrm{~F} 10 \\
(22.4 \mu \mathrm{mol}), \text { and AGS }(4.487 \mu \mathrm{mol}) \text { cells }\end{array}\end{array}$ & [92] \\
\hline
\end{tabular}


Table 4. Cont.

\begin{tabular}{|c|c|c|c|c|c|}
\hline Material & ST & Model & Treatments & Major Findings & Ref. \\
\hline \multicolumn{6}{|c|}{ Neuroprotection } \\
\hline \multirow[t]{2}{*}{ CK from RG } & In vitro & $\begin{array}{l}\text { Glutamate-induced HT22 } \\
\text { (hippocampal) cells }\end{array}$ & $\mathrm{CK}(8,4,2$, and $1 \mu \mathrm{M}), 12 \mathrm{~h}$ & $\begin{array}{c}\downarrow \text { glutamate-induced cytotoxicity } \\
\text { Induced Nrf2 growth in the nucleus } \\
\uparrow \text { expressions of HO- } 1, \text { NQO1, and GR and } \downarrow \text { Nrf2 and Keap1 expressions }\end{array}$ & [93] \\
\hline & In vivo & $\begin{array}{l}\text { Scopolamine-induced } \\
\text { C57BL/6J mice }\end{array}$ & $\begin{array}{c}\mathrm{CK}(10,5 \text {, and } 1 \mathrm{mg} / \mathrm{kg}) \text { daily, } \\
2 \text { weeks }\end{array}$ & $\begin{array}{l}\text { Restored memory and cognitive functions } \\
\text { Modulated Nrf2-mediated cognitive functions }\end{array}$ & \\
\hline CK & In vivo & Diabetic $\mathrm{db} / \mathrm{db}$ mice & $\begin{array}{c}\text { CK }(10 \mathrm{mg} / \mathrm{kg}) \text { per day, } \\
12 \text { weeks }\end{array}$ & $\begin{array}{r}\text { Improved cognitive dysfunction, behavioral impairment, glucose } \\
\text { tolerance and insulin sensitivity, and dyslipidemia } \\
\downarrow \text { fasting glucose levels and } \downarrow \text { IL-1 } \beta \text {, TNF- } \alpha \text {, and IL-6 in the hippocampus } \\
\qquad \begin{array}{c}\uparrow \text { MDA levels } \\
\text { SOD and GSH-Px activities } \\
\text { aTXNIP, NLRP3 inflammasome, ASC, cleaved IL-1 } \beta, \\
\text { and cleaved caspase- } 1\end{array} \\
\downarrow \text { CHOP, BiP p-PERK, p-IRE1 } \alpha \text {, and total ATF6 (Ameliorated ERS) }\end{array}$ & [94] \\
\hline CK & In vivo & $\begin{array}{l}\text { SD rats } \\
\text { Cortical neurons from } \\
\text { C57BL/6 mice }\end{array}$ & $\begin{array}{c}\text { Morphine }(26 \mathrm{nmol} / 10 \mathrm{~mL}) \\
\text { per } \mathrm{h}, \mathrm{CK}(10 \mathrm{mg} / 10 \mathrm{~mL} / \mathrm{h}) \\
7 \text { days }+ \text { naloxone }(10 \mathrm{mg} / \mathrm{kg}) \\
6 \mathrm{~h} \\
\text { CK }(5,1 \text {, and } 0.1 \mathrm{mM}) \\
30 \mathrm{~min}+\underset{\text { morphine }(1 \mathrm{mM})}{6 \mathrm{~h}}\end{array}$ & $\begin{array}{c}\downarrow \text { escape behavior and teeth chattering } \\
\qquad \text { p-ERK, p-NR1 } \\
\downarrow \text { NR1, p-NR1 levels } \\
\text { No significant effect on ERK }\end{array}$ & [95] \\
\hline CK & In vivo & $\mathrm{SD}$ rats & $\begin{array}{l}\text { CK }(120,160 \text {, and } 80 \mathrm{mg} / \mathrm{kg}) \\
\text { twice a day at } 12 \mathrm{~h} \text { interval, } \\
5 \text { days followed by lithium } \\
\text { chloride-pilocarpine or PTZ }\end{array}$ & 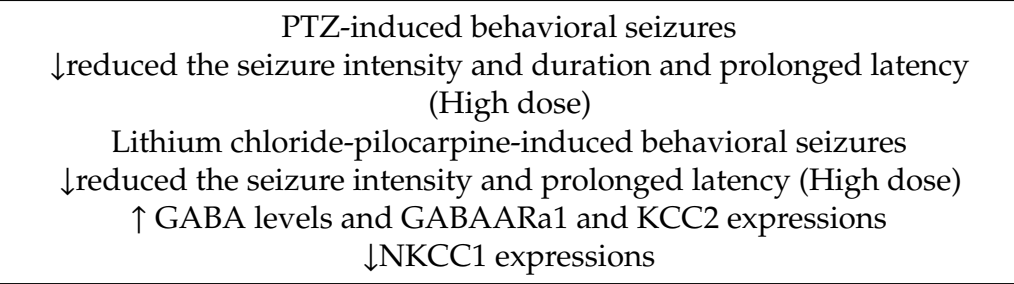 & [96] \\
\hline CK & In vivo & Kunming mice & $\begin{array}{c}\mathrm{CK}(30,10, \text { and } 3 \mathrm{mg} / \mathrm{kg}) \text { since } \\
8 \text { to } 14 \text { day after partial } \\
\text { hepatectomy }\end{array}$ & $\begin{array}{c}\text { Improved MWM test scores of POCD mice } \\
\downarrow \text { TNF- } \alpha \text {, IL- } 1 \beta \text {, and LDL-C serum levels } \\
\uparrow \text { HDL-C levels } \\
\text { In Hippocampal tissues: } \downarrow \text { IL- } 1 \beta \text {, TNF- } \alpha \text {, and NF- } \mathrm{BB} \text { P65 } \\
\uparrow \text { downstream targets of LXR } \alpha-\text { ABCG1, ABCA1, and apoE }\end{array}$ & [97] \\
\hline
\end{tabular}


Table 4. Cont.

\begin{tabular}{|c|c|c|c|c|c|}
\hline Material & ST & Model & Treatments & Major Findings & Ref. \\
\hline CK & In vivo & $\begin{array}{l}\text { Memory-impaired ICR } \\
\text { mice induced with } \\
\text { scopolamine } \\
\text { hydrobromide }\end{array}$ & $\begin{array}{l}\mathrm{CK} 1(\mathrm{CK} 20 \mathrm{mg} / \mathrm{kg}+\mathrm{SCOP} \\
2 \mathrm{mg} / \mathrm{kg}) ; \mathrm{CK} 2(\mathrm{CK} 40 \mathrm{mg} / \mathrm{kg}+ \\
\mathrm{SCOP} 2 \mathrm{mg} / \mathrm{kg}), \text { daily, } 2 \text { weeks }\end{array}$ & $\begin{array}{c}\uparrow \text { memory function } \\
\downarrow \text { neuronal apoptosis and its morphology restored } \\
\text { Inhibited expression of Amyloid } \beta \\
\uparrow \text { SOD and GPx levels and reduced } \downarrow \text { MDA levels } \\
\text { Activated Nrf2/Keap1 signaling pathway }\end{array}$ & {$[98]$} \\
\hline CK & In vitro & $\begin{array}{l}\text { Amyloid } \beta \text { peptide } \\
\text { treated HT22 cells }\end{array}$ & $\mathrm{CK}(10,5$, and $2.5 \mu \mathrm{M}), 24 \mathrm{~h}$ & $\begin{array}{c}\uparrow \text { survival rate and restored growth and morphology of HT22 cells } \\
\downarrow \text { apoptosis and expression of amyloid } \beta \text { peptide } \\
\uparrow \text { expressions of GLUT3, GLUT1, IRS2, and IDE } \\
\downarrow \text { expressions of CDK5, GSK3 } \beta \text {, and tau }\end{array}$ & [99] \\
\hline CK & In vivo & SD rats & $\begin{array}{c}\text { CK }(200,100, \text { and } 50 \mathrm{mg} / \mathrm{kg}) \\
8 \text { weeks }\end{array}$ & $\begin{array}{c}\downarrow \text { cognitive discrepancies in vascular dementia rats at } 200 \mathrm{mg} / \mathrm{kg} \\
\text { Ameliorated neuronal damage } \\
\text { Significant } \downarrow \text { of amyloid } \beta 1-42 \\
\uparrow \text { Akt or protein kinase B activity, involved in the PI3K/Akt pathway } \\
\text { leading to } \\
\uparrow G S K 3 \beta \text { and IDE levels }\end{array}$ & [100] \\
\hline CK & In vivo & Wistar rats & $\begin{array}{c}\mathrm{CK}(60 \text { and } 30 \mathrm{mg} / \mathrm{kg} / \text { day }) \\
15 \text { days }\end{array}$ & $\begin{array}{c}\text { Significant } \downarrow \text { in neurobehavioral scores } \\
\downarrow \text { water content in brain tissue at } 60 \mathrm{mg} / \mathrm{kg} / \text { day } \\
\quad \downarrow \text { brain infarct volume ratio } \\
\uparrow \text { SOD and GSH-Px activities and } \downarrow \text { MDA levels } \\
\quad \downarrow \text { expressions of inflammatory molecules }\end{array}$ & [101] \\
\hline CK & In vivo & $\begin{array}{l}\text { Kunming mice } \\
\text { SD rats }\end{array}$ & $\begin{array}{l}\text { CK }(30,10 \text {, and } 3 \mathrm{mg} / \mathrm{kg}) \\
\text { daily once, } 4 \text { weeks } \\
\text { CK }(30,10 \text {, and } 3 \mathrm{mg} / \mathrm{kg}) \\
\text { daily once, } 2 \text { weeks }\end{array}$ & $\begin{array}{c}\text { Improved depressive-like activities in mice } \\
\text { In rats, } \uparrow \text { sucrose preference and body weight } \\
\text { Improved food consumption and crossings in CUMS rats } \\
\uparrow \text { dopamine and 5-HT (serotonin) levels and no effect on norepinephrine } \\
\downarrow \text { expression of neurotransmitter degrading enzymes } \\
\uparrow B D N F, \text { NGF levels and SOD, GPx, and GSH activities }\end{array}$ & [102] \\
\hline CK & In vivo & Kunming mice & $\begin{array}{c}\mathrm{CK}(30,10 \text { and } 3 \mathrm{mg} / \mathrm{kg}), \\
4 \text { weeks }\end{array}$ & $\begin{array}{c}\text { Prevented depressive-and anxiety-like behaviors } \\
\qquad \begin{array}{c}\downarrow \text { MDA level and } \uparrow \text { SOD expression } \\
\downarrow \text { IL- } 1 \beta \text { and IL-18 }\end{array} \\
\text { Inhibited expressions of NLRP3 and cleaved caspase-1 }\end{array}$ & [103] \\
\hline
\end{tabular}


Table 4. Cont.

\begin{tabular}{|c|c|c|c|c|c|}
\hline Material & ST & Model & Treatments & Major Findings & Ref. \\
\hline \multirow[t]{2}{*}{ CK } & In vitro & $\begin{array}{l}\text { Thrombin-induced } \\
\text { EnNSCs }\end{array}$ & CK $(10 \mu \mathrm{M})$ & $\begin{array}{c}\text { Improved sphere-forming ability } \\
\downarrow \text { apoptosis of EnNSCs } \\
\uparrow \text { proliferation of Ki67-positive EnNSCs cells } \\
\uparrow \text { neurogenesis of Doublecortin-positive EnNSCs cells } \\
\text { Activated LXR } \alpha \text { signaling by } \uparrow \text { expressions of HMGB3 and RBBP7 }\end{array}$ & [104] \\
\hline & In vivo & $\begin{array}{l}\text { Thrombin-induced } \\
\text { C57BLC/6 }\end{array}$ & CK (10 mg/kg) & $\begin{array}{l}\text { Improved the neurobehavioral function } \\
\uparrow \text { neurogenesis in cerebral subventricular zone }\end{array}$ & \\
\hline CK & In vivo & $\begin{array}{l}\text { C57BL/6 mice } 2 \text { months } \\
\text { and } 24 \text { months old treated }\end{array}$ & $\begin{array}{l}\text { CK }(15,10 \text {, and } 5 \mathrm{mg} / \mathrm{kg}), \\
3 \text { days. Last CK dose, EdU } \\
\text { treatment for } 24 \mathrm{~h} \text { for cell } \\
\text { proliferation. Neuronal } \\
\text { survival: Last CK dose, } \\
\text { followed by EdU for } 3 \text { days } \\
\text { sacrificed after } 4 \text { weeks }\end{array}$ & $\begin{array}{r}\uparrow E_{\text {EdU-incorporated cells in } 2 \text { months' dose (dose-dependent) and }} 24 \text { months at } 15 \mathrm{mg} / \mathrm{Kg} \\
\text { Tnumber of cells: PCNA labeled/EdU+PCNA labelled and } \\
\text { Ki-67/EdU+Ki-67 positive cells } \\
\text { cells labeled with EdU+ NeuN) } \\
\uparrow \text { BDNF and NT3 levels } \\
\text { cew cells survival and their differentiation into neurons (observed in } \\
\text { Induced phosphorylation of Akt and ERK1/2 at } 10 \mathrm{mg} / \mathrm{Kg} \text { ( } 2 \text { months) } \\
\text { and } 15 \mathrm{mg} / \mathrm{Kg}(24 \text { months) }\end{array}$ & [105] \\
\hline \multicolumn{6}{|c|}{ Anti-aging/skin protection } \\
\hline CK & In vitro & $\mathrm{HaCaT}$ & $\mathrm{CK}(0.01-1 \mu \mathrm{M}), 3 \mathrm{~h}$ & $\begin{array}{c}\uparrow \text { hyaluronic acid production } \\
\uparrow \text { phosphorylation of ERK and Akt }\end{array}$ & [106] \\
\hline CK & In vitro & $\begin{array}{l}\text { Pretreated NIH3T3 cells } \\
\text { HaCaT cells } \\
\text { B16F10 cells }\end{array}$ & $\begin{array}{l}\mathrm{CK}(0-10 \mu \mathrm{M})+\mathrm{UV} \\
\left(30 \mathrm{~mJ} / \mathrm{cm}^{2}\right) \text { irradiation } \\
\text { followed by } \mathrm{CK}, 24 \mathrm{~h}\end{array}$ & $\begin{array}{c}\downarrow \text { MMP1 and COX-2 levels } \\
\text { Restored collagen (I) level } \\
\uparrow \text { TGM, FLG, and HAS-1 and -2 (slight) levels } \\
\uparrow \text { melanin content but no effect on melanin secretion and } \\
\text { tyrosinase activity } \\
\text { Modulated phosphorylation of IкB } \alpha \text { MAPKs, JNK, and ERK }\end{array}$ & [107] \\
\hline BIOGF1K & In vitro & $\begin{array}{l}\text { UVB-treated }(30 \mathrm{~mJ} / \mathrm{cm} 2) \\
\text { NIH3T3 cells }\end{array}$ & $\begin{array}{c}\text { BIOGF1K 30, or } 15 \mathrm{mg} / \mathrm{mL} \text {, } \\
24 \mathrm{~h}\end{array}$ & $\begin{array}{c}\text { No cytotoxicity, Inhibited apoptosis } \\
\text { Repressed morphological changes } \\
\downarrow \text { melanin secretion and restored sirtuin } 1 \text { and type I procollagen levels } \\
\downarrow \text { levels of MMP-1, MMP-2, COX-2 and } \downarrow \text { activity of AP- } 1 \text { and MAPK }\end{array}$ & [108] \\
\hline
\end{tabular}


Table 4. Cont.

\begin{tabular}{|c|c|c|c|c|c|}
\hline Material & ST & Model & Treatments & Major Findings & Ref. \\
\hline CK & In vitro & HaCaT cells & $\begin{array}{l}\mathrm{CK}(5 \mu \mathrm{M}), \text { maclurin }(15 \mu \mathrm{M}) \\
\text { and maclurin } / \mathrm{CK}, 24 \mathrm{~h}\end{array}$ & $\begin{array}{c}\text { No cytotoxicity to HaCaT cells } \\
\downarrow \text { MMP-1 level in combination than in individual treatments }\end{array}$ & [109] \\
\hline \multirow[t]{2}{*}{ CK } & In vivo & $\begin{array}{l}\text { UV-treated }\left(100 \mathrm{~mJ} / \mathrm{cm}^{2}\right) \\
\text { SKH-1 (hairless) mice } \\
\text { DNCB-induced atopic } \\
\quad \text { dermatitis }\end{array}$ & $\begin{array}{l}\text { CK }(0.3 \%) \text {, daily two times, } \\
2 \text { weeks } \\
\text { CK }(0.3 \%) \text {, daily two times, } \\
2 \text { weeks }\end{array}$ & $\begin{array}{r}\text { TEWL value: in UVB treated group }\left(85 \mathrm{~g} / \mathrm{m}^{2} / \mathrm{h}\right) \text { and CK }+ \text { UVB group } \\
\left(57 \mathrm{~g} / \mathrm{m}^{2} / \mathrm{h}\right) \\
\text { and in DNCB-treated group ( } 65 \mathrm{~g} / \mathrm{m} 2 / \mathrm{h}) \text { decreased to }(42 \mathrm{~g} / \mathrm{m} 2 / \mathrm{h}) \text { in CK }+ \\
\text { DNCB group } \\
\text { Improved skin hydration: } 37 \% \text { from } 31 \% \text { (UV-treated) and } 28 \% \text { from } 20 \% \\
\text { (DNCB-treated) } \\
\text { CK improved epidermal hyperkeratosis } \\
\text { Suppressed skin thickness to } 73.5 \% \text { in the UV model and } 50.5 \% \text { in the } \\
\text { DNCB model } \\
\uparrow \text { SPINK5 levels and } \downarrow \text { KLK-5 and PAR2 in both models }\end{array}$ & \multirow[t]{2}{*}{ [110] } \\
\hline & In vitro & $\begin{array}{l}\text { HaCaT cells UV-treated } \\
\qquad\left(15 \mathrm{~mJ} / \mathrm{cm}^{2}\right)\end{array}$ & $\mathrm{CK}(30,10,3$, and $1 \mu \mathrm{M}), 24 \mathrm{~h}$ & $\downarrow$ SPINK expression by decreasing KLK-7, -5 and PAR2 & \\
\hline \multirow[t]{2}{*}{ CK } & In vivo & $\begin{array}{l}\text { Imiquimod } \\
\text { (IMQ)-induced } \\
\text { psoriasis-like dermatitis } \\
\text { C57BL/6 female mice }\end{array}$ & $\begin{array}{c}\text { CK }(0.1 \% \text { and } 1 \%) \\
\text { next three days }\end{array}$ & $\begin{array}{l}\text { CK }(1 \%) \text { suppressed imiquimod-induced keratinocyte proliferation } \\
\downarrow \text { epidermal thicknesses } \downarrow \text { RegIII } \gamma \text { expression in IMQ-treated mouse } \\
\text { keratinocytes }\end{array}$ & \multirow[t]{2}{*}{ [111] } \\
\hline & In vitro & HaCaT cells & $\begin{array}{l}\text { CK }(2,1.6,1.2,0.8 \\
\text { and } 0.4 \mu \mathrm{g} / \mathrm{mL})+\mathrm{IL}-36 \gamma \\
\qquad(\mu \mathrm{g} / \mathrm{mL})\end{array}$ & 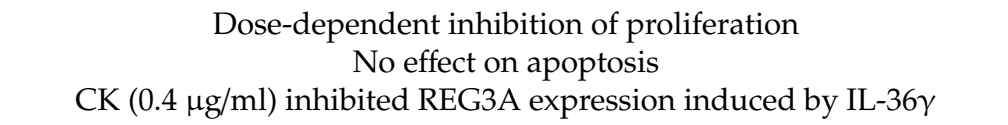 & \\
\hline \multicolumn{6}{|c|}{ Others } \\
\hline CK & In vivo & $\begin{array}{l}\text { UUO C57BL/6 mice } \\
\text { after) UUO induction I/R } \\
\text { injury with unilateral } \\
\text { NX model }\end{array}$ & $\begin{array}{l}\text { CK ( } 30 \mathrm{mg} / \mathrm{kg} \text { body wt.) } \\
\text { therapeutic group (1 day } \\
\text { before), preventive group } \\
\text { ( } 3 \text { days) + one day after } \\
\text { ligation of renal vessels }\end{array}$ & $\begin{array}{c}\text { UUO model, } \downarrow \text { NLRP3 inflammasome activation in } \\
\text { kidney } \uparrow \text { ribosome-governed activation } \\
\text { Prevented renal tubulointerstitial lesions in the kidney } \\
\downarrow \text { TNF- } \alpha \text {, IL-6, IL-1 } \beta \text {, and MCP- } 1 \text { in urine } \\
\text { Inhibited activation of T-cells and NF- } \mathrm{B} B \\
\text { Improvement kidney pathology and kidney function in NX + I/R model } \\
\text { (Therapeutic effects) }\end{array}$ & [112] \\
\hline
\end{tabular}


Table 4. Cont.

\begin{tabular}{|c|c|c|c|c|c|}
\hline Material & ST & Model & Treatments & Major Findings & Ref. \\
\hline & In vitro & $\begin{array}{l}\text { M-1 under MICP } \\
\text { J774A.1 macrophages }\end{array}$ & $\begin{array}{l}\mathrm{CK}(10 \mu \mathrm{M}), 30 \mathrm{~min} \mathrm{CK}(0-10 \\
\mu \mathrm{M}), 30 \mathrm{~min}+\mathrm{LPS}, 5.5 \mathrm{~h}\end{array}$ & $\begin{array}{l}\downarrow \text { caspase-1, IL-1 } \beta \text { NF- } \kappa \text { B } p 65 \text {, and NLRP3 in M-1 cells } \\
\text { Suppressed NLRP3 expression by } \downarrow \text { NF- } \kappa \text { B activation in macrophages } \\
\downarrow \text { phosphorylation and activity of STAT3 in activated macrophages }\end{array}$ & \\
\hline \multirow[t]{2}{*}{ CK (M1) } & In vivo & $\begin{array}{l}\text { LPS-induced NZB/WF1 } \\
\text { mice }\end{array}$ & M1 (50 mg/kg) & 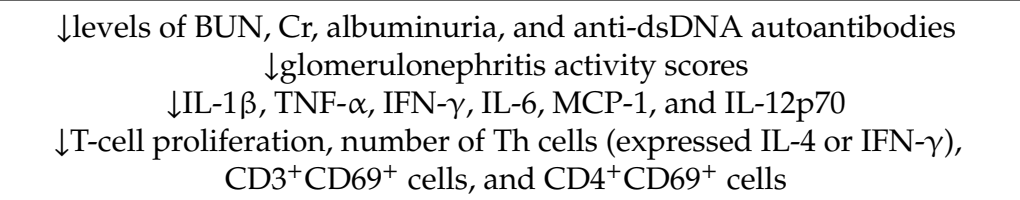 & \multirow[t]{2}{*}{ [113] } \\
\hline & In vitro & $\begin{array}{l}\text { LPS-treated BMDCs, } \\
\text { podocytes }\end{array}$ & $\begin{array}{l}\text { M1 }(10 \mu \mathrm{M}), 30 \mathrm{~min}+\text { with or } \\
\text { without LPS }(100 \mathrm{ng} / \mathrm{mL}), 6 \mathrm{~h}\end{array}$ & $\downarrow$ ROS production and inhibited activation of NLRP3 inflammasome & \\
\hline CK analogues & In vivo & $\begin{array}{l}\text { OVA-sensitized asthmatic } \\
\text { mouse }\end{array}$ & $\begin{array}{l}\text { CK and its analogues } \\
(20 \mathrm{mg} / \mathrm{kg}) \text { for } 7 \text { days }\end{array}$ & $\begin{array}{c}\text { Comparable anti-asthmatic effects of CK analogues T1, T2, T3, } \\
\text { T8 and T12 } \\
\text { IgE }(\mathrm{ng} / \mathrm{mL}) \text { value }=\mathrm{CK}(1501.85 \pm 184.66), \mathrm{T} 1(1237.11 \pm 106.28) \\
\mathrm{T} 2(975.82 \pm 160.32), \mathrm{T} 3(1136.96 \pm 121.85), \mathrm{T} 8(1191.08 \pm 107.59) \text { and T12 } \\
(1258.27 \pm 148.70)\end{array}$ & [114] \\
\hline
\end{tabular}


Table 4. Cont.

Material Treatments Major Findings Ref. $\uparrow$ cell survival and $\downarrow$ cell damage

ROS production and mitochondrial damage $\downarrow$ production of phagocytic precursors
CK
In vitro
$\mathrm{H} 9 \mathrm{c} 2$ cells
$\mathrm{CK}(2,4$, and $8 \mu \mathrm{M}), 48 \mathrm{~h}$

$\downarrow$ Bax/Bcl-2 ratio, cleaved caspase-3 and PARP

$\downarrow$ p-Beclin-1/beclin-1ratio, Atg5, Atg7, LC3II/I

$\uparrow$ P62 expression

CK, compound K; ST, study type; COX-2, cyclooxygenase-2; IL, interleukin; PI3K, phosphatidylinositol 3 kinase; Akt, protein kinase B; mTOR, mammalian target of rapamycin; GSK3 3 , glycogen synthase kinase 3 $3 ; \mathrm{Bcl} 2$, B-cell lymphoma-2; JNK, c-Jun N-terminal kinase; AP-1 (also known as c-jun); LC3, microtubule-associated protein 1A/1B-light chain 3; PARP, poly (ADP-ribose) polymerase; AMPK, $5^{\prime}$ AMP-activated protein kinase; NSCLC, non-small cell lung cancer; PDK1, 3-Phosphoinositide-dependent protein kinase 1; HKII, mitochondrial hexokinase II; LDHA, lactate dehydrogenase A; HIF-1 $\alpha$, hypoxia-inducible factor 1; GLUT, glucose transporter; CDK-4, cyclin-dependent kinase-4; Bax, B-cell lymphoma 2 (BCL-2)-associated $X$ protein; ERS, endoplasmic reticulum stress; STAT3, signal transducer and activator of transcription 3; p-STAT3, phosphorylated-STAT3; CHOP, C/EBP homologous protein; GRP78, glucose-regulated protein-78; PERK, protein kinase-like endoplasmic reticulum kinase; IRE1, inositol-requiring enzyme 1 ; NF-kB, nuclear factor-kB; $p$-elF2 $\alpha$, phospho-eukaryotic translation initiation factor 2 subunit $\alpha$; XBP-1S, X-box binding protein-1S; Bip, binding immunoglobulin protein; Mcl-1, myeloid cell leukemia 1; XIAP, X-linked inhibitor of apoptosis protein; cFLIP, fas-associated death domain-like IL-1-converting enzyme-inhibitory protein; tBid, truncated BID; DR5, death receptor 5; Atg7, autophagy-related 7; TUNEL, TdT-mediated dUTP nick end labelling; ROS, reactive oxygen species; BECN, Beclin-1; SDF-1, stromal cell-derived growth factor 1; PKC $\alpha$, protein kinase C $\alpha$; ERK, extracellular signal-regulated kinase; CXCR-4, C-X-C chemokine receptor type 4; IC 50 , half maximal inhibitory concentration; p70S6K1; ribosomal protein S6 kinase $\beta$ 1; PTEN, phosphatase and tensin homolog; GCK, ginsenoside CK; GCKT, GCK with TPGS; TPGS, D- $\alpha$-tocopheryl polyethylene glycol 1000 succinate; PEG, polyethylene glycol; PCL, polycaprolactone; MMP, matrix metalloproteinase; AP, ascorbyl palmitate; PC, phosphatidylcholine; DP, 1,2-distearoyl-sn-glycero-3-phosphoethanolamine polyethylene glycol 2000; BSA, bovine serum albumin; NP, nanoparticles; NO, nitric oxide; OCMC, O-carboxymethyl chitosan; APD-CK, A54-PEG-DA-OCMC polymer CK-loaded micelle; ROS, reactive oxygen species; tLyP-1, truncated form of the cyclic tumor-homing peptide LyP-1; RG, red ginseng; Nrf2, nuclear factor (erythroid-derived 2)-like 2; HO-1, heme oxygenase-1; NQO1, NAD(P)H dehydrogenase [quinone] 1; GR, glutathione reductase; Keap1, Kelch-like ECH associated protein 1; TNF- $\alpha$, tumor necrosis factor alpha; MDA, malondialdehyde; iNOS, inducible nitric oxide synthase; MAPKs, mitogen-activated protein kinases; SOD, superoxide dismutase; GSH, glutathione; TXNIP, thioredoxin-interacting protein; NLRP3, NOD-like receptor protein-3; ASC, apoptosis-associated speck-like protein containing a CARD; p-IRE1 $\alpha$, phospho-IRE1 alpha; ATF6, activating transcription factor 6; SD, Sprague-Dawley; p-PERK, phospho-PERK; p-NR1, phospho-N-methyl-D-aspartate acid receptor subunit 1; p-ERK, phospho-ERK; PTZ, pentylenetetrazole; GABA, gamma amino-butyric acid; GABA $\mathrm{A}_{\mathrm{A}} \alpha 1$, GABA type A receptor subunit alpha1; KCC2, K-Cl cotransporter isoform 2; NKCC1, Na-K-2Cl cotransporter isoform 1; MWM, Morris water-maze; POCD, post-operative cognitive dysfunction; LDL-C, low density lipoprotein-cholesterol; HDL-C, high density lipoprotein-cholesterol; $\mathrm{LXR} \alpha$, liver X receptor alpha; ABCG1/A1, ATP-binding cassette transporter G1/A1; apoE, apolipoprotein E; ICR, imprinting control region; GPx, glutathione peroxidase; IRS2, insulin receptor substrates 2; IDE, insulin-degrading enzyme; CDK, cyclin-dependent kinase; CUMS, chronic unpredictable mild stress; BDNF, brain derived neurotrophic factor; NGF, nerve growth factor; EnNSCs, endogenous neural stem cells; HMGB3, High mobility group protein B3; RBBP7, RB binding protein 7; EdU, 5-ethynyl-20-deoxyuridine; PCNA, proliferating cell nuclear antigen; NT3, neurotrophin-3; NeuN, neuronal nuclear protein; TCM, transglutaminase; FLG, filaggrin; HAS, hyaluronic acid synthases; IKB $\alpha$, inhibitor of mechanically induced constant pressure; LPS, lipopolysaccharide; BMDCs, bone marrow-derived dendritic cells; OVA, ovalbumin. 
The bioactivity of CK has been described by inhibiting viability and proliferation, inducing apoptosis, by blocking the PI3K/mTOR/p70S6K1 signaling pathway (Table 4) [90]. Recently, many studies have been published comparing the health-promoting activities of CK and its derivatives (Table 4). Yang et al. identified the liposomal mediated improved anti-cancer activity of CK. They found that using GCKT-liposomes, the cellular uptake of GCK by lung adenocarcinoma (A549) cell line increased by enhancing time treatments $(1,2$, and $4 \mathrm{~h})$. The anti-tumor efficacy of GCKT-liposomes was observed to be more compared to CK. The use of GCKT-liposomes was advocated to overcome problems such as insufficient drug packaging, instable nature, rapid drug discharge, and poor blood circulation of conventional liposomes [33].

Similarly, CK-M described earlier in this review, were used for in vitro (A549 and PC-9) and in vivo models. The apoptosis percentage of CK-M was higher than free CK. Meanwhile, CK-M also displayed an improved tumor inhibitory effect in vivo [36]. The anti-lung cancer effects (in vitro and in vivo) of CK AP/TPGS mixed micelles [37] and CK PC/DP micellar system [38] have also been documented. Moreover, using in vitro models, BSA-CK NPs showed more significant cytotoxic effects in the liver carcinoma (HepG2), skin cell line (HaCaT), A549 cells, and colon cancer cell line (HT29) compared to monomer CK. However, for in vivo application, authors advocated the use of human serum albumin as an alternative to BSA to evade plausible immunologic concerns in humans [39]. In addition, CK-loaded GNPs have been identified as effectual photothermal and chemotherapeutic agents [40]. On a similar line, a higher dose-dependent inhibitory effect of chitosan nanoparticles loaded with CK (CK-NPs) was observed compared to $\mathrm{CK}$. Authors described a lower $\left(\mathrm{IC}_{50}=16.58 \mu \mathrm{g} / \mathrm{mL}\right)$ value for CK-NPs compared to $\mathrm{CK}\left(\mathrm{IC}_{50}=23.33 \mu \mathrm{g} / \mathrm{mL}\right)$ in HepG2 cells [41]. Likewise, $\mathrm{CK}$ loaded O-OCMC nanoparticles showed inhibitory effects against prostate cancer (PC3) cells through enhanced cytotoxicity and uptake of CK [42]. Chitosan polymer micelles decorated using A54 peptide, known as APD-CK, were utilized against Huh-7 and HepG2 cells. APD-CK showed higher cytotoxicity compared to CK and promoted apoptosis of HepG2 cells (Table 4) [43]. In another study, tLyp-1 (tumor-homing peptide) decorated liposomes loaded with parthenolide (active anti-tumor agent isolated from Tanacetum parthenium) and CK have been evaluated as lung cancer-targeting system. Enhanced anti-tumor activity was observed against both the cell line and animal model with limited adverse effects. In A549 cells, CK/parthenolide tLyp-1 liposomes decreased mitochondrial membrane potential and allowed greater $\mathrm{Ca}^{2+}$ efflux as well as significant inhibition of cell migration. From in vivo study, it was found that the complex has greater anti-tumor activity than the combination of these substances [91].

In another study, a derivative of CK, known as CKGal (20-O- $\beta$-D-lactopyranosyl-20(S)protopanaxadiol) have been produced using $\beta-1,4$-galactosyltransferase, a regiospecific enzyme. The anti-proliferative action of CKGal was evaluated on skin melanoma (B16F10), brain carcinoma (U87MG), gastric cancer cell lines (AGS), and cervical carcinoma (HeLa). The CKGal displayed the best cytotoxicity against skin melanoma and cervical carcinoma compared to $\mathrm{CK}$, Rh2, and F12 [92].

\subsection{Neuroprotection}

Several studies have documented the therapeutic effects of ginseng and ginsenosides in many central nervous system (CNS) ailments, for instance, Alzheimer's disease, Parkinson's disease, depression, and other ailments [6]. The protection could be ascribed to reducing neuroinflammation, neuroprotection, and regulating neurotransmitter release. In previous articles, the cognitive and neuroprotective role of CK has been described $[3,11]$. The current review summarizes the recent progress in neuroprotection effects of CK (Table 4).

In a study, CK (derived from red ginseng) was able to exert neuroprotective effects in memoryimpaired mouse (scopolamine-induced) model by inducing nuclear factor (erythroid-derived 2)-like 2 (Nrf2)-facilitated antioxidants. No effect was observed on the acetylcholine esterase (AChE) activity. In addition to that, CK defense against glutamate-induced cytotoxicity was also observed in HT-22 cells [93]. Recently, CK was found to be protective against memory and cognitive impairment in $\mathrm{db} / \mathrm{db}$ mice by suppressing inflammation and oxidative stress, ameliorating dyslipidemia, insulin 
sensitivity, glucose tolerance as well as modulating ER stress and NLRP3 inflammasome pathway (Table 4) [94]. Moreover, in another study, CK minimized the morphine dependency by decreasing N-methyl-D-aspartate acid receptor subunit 1 activation in cultured cortical neurons from mice and frontal cortex of rat brains [95]. Another recent research documented the protective effects of CK against epilepsy in status epilepticus (SE) rat model. Compound K stimulated the release of gamma amino-butyric acid (GABA) and enhanced the GABA type A receptor subunit alpha1-facilitated inhibitory synaptic transmission [96]. In addition to the anti-atherosclerosis effects of CK and its derivatives as described above [68], the role of LXR $\alpha$ in immunomodulation has also been described in continuous research. Researchers demonstrated that $\mathrm{CK}$ was able to mitigate post-operative cognitive dysfunction (POCD). They found that CK inhibited hippocampal inflammation by activating LXR $\alpha$. CK attenuated memory dysfunction by modulating Morris water-maze (MWM) test scores in an aged mouse model (Table 4) [97].

Regulation of aggregated amyloid- $\beta(A \beta)$ is an important part of Alzheimer's disease (AD) treatment. Concerning this, $C K$ was found to enhance memory function, reduce $\mathrm{A} \beta$ expression and aggregation, and neuronal apoptosis by activating the Nrf2/Kelch-like ECH-associated protein-1 signaling pathway in ICR mice with diminished memory. Furthermore, the defensive effects were also due to the activation of the antioxidant system [98]. Likewise, the influence of the CK was elucidated using A $\beta$ peptide-induced HT22 cells by improving viability, growth, and apoptosis of HT22 cells, as well as localization and expression of A $\beta$ peptide in cells. Besides, ATP levels of cells were enhanced by increasing the activity of glucose transporters. Compound $\mathrm{K}$ restored abnormal energy metabolism (A $\beta$ induced) by modulating the expressions of several enzymes (Table 4) [99]. Zong et al. first found that the $C K$ mitigates cerebral discrepancies and $A \beta_{1-42}$ accumulation in the hippocampus of chronic cerebral hypoperfusion-induced vascular dementia SD rats by enhancing the pSer9Glycogen synthase kinase-3b expression. To add further, CK upregulated PI3K/Akt pathway, resulting in increased insulin-degrading enzyme activity, a central enzyme accountable for degrading $A \beta_{1-42}$ in the brain (Table 4) [100].

In an in vivo research, $\mathrm{CK}$ pretreatment resulted in the reduction of neurobehavioral score, water in brain tissue, and the cerebral infarct volume ratio against cerebral ischemia/reperfusion (I/R) injury in Wistar rats. Compound K enhanced activities of antioxidant enzymes, decreased levels of IL-1 $\beta$, TNF- $\alpha$, and declined level of high mobility group box 1 protein. Generally, the protective effects of CK against cerebral I/R damage may be due to anti-inflammatory and antioxidant bioactivities [101]. The earlier reviews have described the neuroprotective role of CK [3]. However, its antidepressant effect has been described recently. Depression is a global societal health concern. Concerning the effect of CK on depression, a study used two models: behavioral despair model (mice) and the chronic unpredictable mild stress (CUMS, rats) model. The antidepressant role may be due to regulation of the concentration of monoamine neurotransmitters, enhanced antioxidant capacity, and increased expressions of neuronal growth factor and brain-derived neurotrophic factor in the CNS [102]. In a follow-up study, the defensive effect of CK on CUMS depression was evaluated by inhibiting oxidative stress, inflammatory cytokines and NLRP3 expression using a mouse model [103].

Amongst others, recent work on explaining the beneficial effects of CK on hippocampal neurogenesis has been published. In one study, CK was found to induce neurogenesis and decrease apoptosis in thrombin-induced endogenous neural stem cells (EnNSCs) and improve animal prognosis by stimulating $\mathrm{LXR} \alpha$ activation [104]. In another study, CK treatment triggered the proliferation of fresh cells and substantially increased their differentiation in the hippocampus (dentate gyrus) by activating brain derived neurotrophic factor (BDNF) signaling. The higher dose of CK was found to be more effective in aged mice compared to young ones (Table 4) [105].

\subsection{Anti-Aging/Skin Protection}

It is well-known that the production and synthesis of hyaluronic acid (HA) decreases with age. A study by Lim et al. identified that CK led to increased production of HA by activating Src (tyrosine 
kinase)-dependent Akt and ERK [106]. Ultraviolet type B (UVB) radiation induces photo- aging due to collagen degradation (type I and III) and increased production of iNOS, COX-2, and MMPs. Compound K supplementation diminished production of COX-2 and MMP-1 in NIH3T3 cells treated with UVB, and expression of type I collagen was modulated. Compound $\mathrm{K}$ also displayed the ability to improve the skin's moisture level. The study also found skin hydration effects of CK in HaCaT cells (Table 4) [107]. Compound K-rich fraction applied to UVB-treated cells was equally successful in the prevention of UVB-mediated aging [108]. Interestingly, the effectiveness against reducing mRNA expression of MMP-1 was more in a synergistic approach by CK and maclurin (a natural compound) compared to individual compounds [109]. Another study assessed the role of CK in improving skin barrier function by upregulating the expression of serine protease inhibitor Kazal type-5 in atopic dermatitis-like mice and UVB-irradiated mouse model [110]. In recent research, CK improved imiquimod-induced psoriasis by inhibiting regenerating islet-derived protein 3 (RegIII) gamma expression in the mouse model and IL-36 $\gamma$-induced Reg3A expression in human keratinocytes (Table 4) [111]. These findings advocate that CK plays a key role in the defense and anti-aging effects.

\subsection{Others}

Recently, a patented study investigating the beneficial effects of $C K$ on renal tubulointerstitial lesions in C57BL/6 mice with unilateral ureteral obstruction identified the kidney-protective effects of CK. The results showed reduced production of pro-inflammatory cytokines and the prevention of leukocytes infiltration and fibrosis in the kidney. The positive outcomes were showcased by inhibiting NF-KB-associated priming, and by modulating STAT3 signaling and NLRP3 inflammasome activation (Table 4) [112]. Likewise, another study showed the protecting effects of CK on accelerated and severe lupus nephritis by hindering activation of NLRP3 inflammasome [113]. Ren and coworkers evaluated the protecting effects of $\mathrm{CK}$ and its analogues against asthma. Compound $\mathrm{K}$ and its analogues displayed a significant impact by reducing $\mathrm{IgE}$ and airway resistance [114]. Compound $\mathrm{K}$ pretreatment was reported to protect against cardiac I/R by activating the PI3K-Akt signaling pathway, which is crucial for autophagy-triggered apoptosis (Table 4) [115].

\subsection{Clinical Studies}

\subsubsection{Anti-Diabetic}

Clinical studies evaluated the bioactivities of hydrolyzed ginseng extract. Recently, a double-blind, randomized controlled trial assessed the anti-glycaemic effects of hydrolyzed ginseng extract (GINST15, rich in $\mathrm{CK}$ ) on prediabetic participants for 12 months. GINST15 resulted in improved fasting and 1-hour postprandial glucose levels. No effect was observed on 2-hour postprandial glucose levels [116]. An earlier clinical study also confirmed these results in which fermented red ginseng extract supplementation decreased fasting glucose, postprandial glucose levels and improved insulin levels in type 2 diabetic subjects compared to placebo [117].

\subsubsection{Neuroprotection}

Flanagan et al. have documented the effects of GINST15 on hypo-pituitary-adrenal (HPA) and antioxidant activity clinically. In this double-blind, placebo-controlled, counterbalanced within-group study design different doses (high dose-960 mg and low dose-160 mg) of CK were given for 2 weeks. They found that, in response to severe exercise, CK supplementation resulted in dose-dependent declines in circulating cortisol and augmented antioxidant activity. This study first provided insights into the impact of ginseng treatment on the reactions to the stress associated with work [118]. A recent continued study by the same research group demonstrated direct evidence on task-related brain activity by evaluating CK's treatment on behavioral performance and electroencephalography measures of cortical activity. After exercise, the upper and lower body response times were improved. Compound $\mathrm{K}$ augmented activity in cortical regions accountable for sustained attention, whereas exercise-triggered 
increases in arousal were diminished. In short, CK has been found to have inducible effects on the activity of the brain [119].

\subsubsection{Liver Protection}

As mentioned above, in an in vivo study, GBCK25 has been found to have defensive effects against NASH [55]. On a similar line, recent research evaluated the protective effects of GBCK25 on liver function in a 12-week, randomized, double-blind clinical trial. The supplementation includes GBCK25 tablets (high (500) and low (125) mg/day) and placebo. Treatment at a low dose significantly reduced gamma-glutamyl transferase and high-sensitivity C-reactive protein levels in male participants, while high dose abridged fatigue score significantly. No side effects were observed for the supplementation. The study indicated that GBCK25 is safe and can improve liver function [120].

\section{Concluding Remarks}

The review aimed at providing current information concerning the pharmacokinetics, safety, and health-promoting activities of $\mathrm{CK}$ and its derivatives for preventing and managing diseases. It is well known that the CK is more bioavailable than its parent saponins and has several health benefits. Although more bioavailable than major ginsenosides, CK has certain drawbacks that restrict its clinical use. The use of CK derivatives as nanocarriers were shown to have better permeability, solubility, and efflux, including enhanced health-promoting activities. The review provides new insight into CK derivatives to increase the metabolic proficiency of CK. Most health-promoting activities were in vitro and in vivo, including hepatoprotective, anti-inflammatory, anti-atherosclerosis, anti-cancer, neuroprotection, skin protection, and anti-aging. Besides, the limited number of clinical studies have also been documented. The diverse bioactivities of CK were based on modulating complicated signaling pathways and targeting various molecules. Compound $\mathrm{K}$ has been found to attenuate the activities of AMPK, MAPK, NF-kB, PI3K/Akt, mTOR/AMPK, JNK PI3K/mTOR/p70S6K1 signaling pathways. Overall, pharmacokinetic studies on monomer CK and its preclinical and clinical safety information data are limited. Further investigations are warranted to appraise the efficacy and safety of CK and its derivatives, especially in clinical studies.

Author Contributions: H.-J.L. was responsible for the conceptualization, writing, editing, supervision, project management, and funding; H.-J.L. and A.S. designed the study. A.S. wrote the manuscript; H.-J.L. reviewed the manuscript intensively; H.-J.L. and A.S. edited the manuscript. Both authors have read and agreed to the published version of the manuscript.

Funding: This study was supported by a grant "Cooperative Research Program of Center for Companion Animal Research (Project No. PJ01398402)" Rural Development Administration and partly supported by Korea Food Research Institute (E0164500-05), Republic of Korea.

Conflicts of Interest: The authors declare no conflict of interest.

\section{References}

1. Yun, T.-K. Panax ginseng-A non-organ-specific cancer preventive? Lancet Oncol. 2001, 2, 49-55. [CrossRef]

2. Lee, J.-O.; Choi, E.; Shin, K.K.; Hong, Y.H.; Kim, H.G.; Jeong, D.; Hossain, M.A.; Kim, H.S.; Yi, Y.-S.; $\mathrm{Kim}$, D.; et al. Compound $\mathrm{K}$, a ginsenoside metabolite, plays an antiinflammatory role in macrophages by targeting the AKT1-mediated signaling pathway. J. Ginseng Res. 2018, 43, 154-160. [CrossRef] [PubMed]

3. Oh, J.; Kim, J.-S. Compound K derived from ginseng: Neuroprotection and cognitive improvement. Food Funct. 2016, 7, 4506-4515. [CrossRef] [PubMed]

4. Yang, L.; Zou, H.; Gao, Y.; Luo, J.; Xie, X.; Meng, W.; Zhou, H.; Tan, Z. Insights into gastrointestinal microbiota-generated ginsenoside metabolites and their bioactivities. Drug Metab. Rev. 2020, 52, 125-138. [CrossRef]

5. Lee, I.-S.; Kang, K.; Kim, S.-Y. Panax ginseng Pharmacopuncture: Current Status of the Research and Future Challenges. Biomolecules 2019, 10, 33. [CrossRef] 
6. Kim, K.H.; Lee, D.; Lee, H.L.; Kim, C.-E.; Jung, K.; Kang, K. Beneficial effects of Panax ginseng for the treatment and prevention of neurodegenerative diseases: Past findings and future directions. J. Ginseng Res. 2018, 42, 239-247. [CrossRef]

7. Noh, K.-H.; Oh, D.-K. Production of the Rare Ginsenosides Compound K, Compound Y, and Compound Mc by a Thermostable $\beta$-Glycosidase from Sulfolobus acidocaldarius. Biol. Pharm. Bull. 2009, 32, 1830-1835. [CrossRef]

8. Akao, T.; Kida, H.; Kanaoka, M.; Hattori, M.; Kobashi, K. Drug Metabolism: Intestinal Bacterial Hydrolysis is Required for the Appearance of Compound K in Rat Plasma after Oral Administration of Ginsenoside Rb1 from Panax ginseng. J. Pharm. Pharmacol. 1998, 50, 1155-1160. [CrossRef]

9. Zhou, L.; Chen, L.; Zeng, X.; Liao, J.; Ou-Yang, D.-S. Ginsenoside compound K alleviates sodium valproate-induced hepatotoxicity in rats via antioxidant effect, regulation of peroxisome pathway and iron homeostasis. Toxicol. Appl. Pharmacol. 2020, 386, 114829. [CrossRef]

10. Christensen, L.P. Ginsenosides: Chemistry, biosynthesis, analysis, and potential health effects. Adv. Food Nutr. Res. 2008, 55, 1-99.

11. Yang, X.-D.; Yang, Y.-Y.; Ou-Yang, D.-S.; Yang, G.-P. A review of biotransformation and pharmacology of ginsenoside compound K. Fitoterapia 2015, 100, 208-220. [CrossRef] [PubMed]

12. Hasegawa, H.; Sung, J.-H.; Matsumiya, S.; Uchiyama, M. Main Ginseng Saponin Metabolites Formed by Intestinal Bacteria. Planta Medica 1996, 62, 453-457. [CrossRef] [PubMed]

13. Kim, D.-H. Chemical Diversity of Panax ginseng, Panax quinquifolium, and Panax notoginseng. J. Ginseng Res. 2012, 36, 1-15. [CrossRef] [PubMed]

14. Upadhyaya, J.; Kim, M.-J.; Kim, Y.-H.; Ko, S.-R.; Park, H.-W.; Kim, M.-K. Enzymatic formation of compound-K from ginsenoside $\mathrm{Rb} 1$ by enzyme preparation from cultured mycelia of Armillaria mellea. J. Ginseng Res. 2015, 40, 105-112. [CrossRef]

15. Li, D.; Wu, Y.; Zhang, C.; Sun, J.; Zhou, Z.; Lu, W. Production of Triterpene Ginsenoside Compound K in the Non-conventional Yeast Yarrowia lipolytica. J. Agric. Food Chem. 2019, 67, 2581-2588. [CrossRef]

16. Oh, J.-M.; Kim, E.; Chun, S. Ginsenoside Compound K Induces Ros-Mediated Apoptosis and Autophagic Inhibition in Human Neuroblastoma Cells In Vitro and In Vivo. Int. J. Mol. Sci. 2019, 20, 4279. [CrossRef]

17. Kim, K.-A.; Yoo, H.H.; Gu, W.; Yu, D.-H.; Jin, M.J.; Choi, H.-L.; Yuan, K.; Guérin-Deremaux, L.; Kim, D.-H. A prebiotic fiber increases the formation and subsequent absorption of compound $\mathrm{K}$ following oral administration of ginseng in rats. J. Ginseng Res. 2014, 39, 183-187. [CrossRef]

18. Lee, J.; Lee, E.; Kim, N.; Lee, J.; Yoo, J.; Koh, B. Studies on absorption, distribution and metabolism of ginseng in humans after oral administration. J. Ethnopharmacol. 2009, 122, 143-148. [CrossRef]

19. Choi, I.-D.; Ryu, J.-H.; Lee, N.-E.; Lee, M.-H.; Shim, J.-J.; Ahn, Y.-T.; Sim, J.-H.; Huh, C.-S.; Shim, W.-S.; Yim, S.-V.; et al. Enhanced Absorption Study of Ginsenoside Compound K (20-O- $\beta$-(D-Glucopyranosyl)20(S)-protopanaxadiol) after Oral Administration of Fermented Red Ginseng Extract (HYFRG ${ }^{\mathrm{TM}}$ ) in Healthy Korean Volunteers and Rats. Evidence-Based Complement. Altern. Med. 2016, 2016, 3908142. [CrossRef]

20. Dong, W.-W.; Han, X.-Z.; Zhao, J.; Zhong, F.-L.; Ma, R.; Wu, S.; Li, D.; Quan, L.-H.; Jiang, J. Metabolite profiling of ginsenosides in rat plasma, urine and feces by LC-MS/MS and its application to a pharmacokinetic study after oral administration of Panax ginseng extract. Biomed. Chromatogr. 2017, 32, e4105. [CrossRef]

21. Igami, K.; Ozawa, M.; Inoue, S.; Iohara, D.; Miyazaki, T.; Shinoda, M.; Anraku, M.; Hirayama, F.; Uekama, K. The formation of an inclusion complex between a metabolite of ginsenoside, compound $\mathrm{K}$ and ?-cyclodextrin and its dissolution characteristics. J. Pharm. Pharmacol. 2015, 68, 646-654. [CrossRef]

22. Kim, J.S.; Kim, Y.; Han, S.-H.; Jeon, J.-Y.; Hwang, M.; Im, Y.-J.; Lee, S.Y.; Chae, S.-W.; Kim, M.-G.; Kim, J.H. Development and validation of an LC-MS/MS method for determination of compound $\mathrm{K}$ in human plasma and clinical application. J. Ginseng Res. 2013, 37, 135-141. [CrossRef] [PubMed]

23. Jin, H.; Seo, J.-H.; Uhm, Y.-K.; Jung, C.-Y.; Lee, S.-K.; Yim, S.-V. Pharmacokinetic comparison of ginsenoside metabolite IH-901 from fermented and non-fermented ginseng in healthy Korean volunteers. J. Ethnopharmacol. 2012, 139, 664-667. [CrossRef] [PubMed]

24. Fukami, H.; Ueda, T.; Matsuoka, N. Pharmacokinetic Study of Compound K in Japanese Subjects After Ingestion of Panax ginseng Fermented by Lactobacillus paracasei A221 Reveals Significant Increase of Absorption into Blood. J. Med. Food 2019, 22, 257-263. [CrossRef] [PubMed] 
25. Shimojo, Y.; Ozawa, Y.; Toda, T.; Igami, K.; Shimizu, T. Probiotic Lactobacillus paracasei A221 improves the functionality and bioavailability of kaempferol-glucoside in kale by its glucosidase activity. Sci. Rep. 2018, 8, 9239. [CrossRef]

26. Jin, S.; Jeon, J.-H.; Lee, S.; Kang, W.Y.; Seong, S.J.; Yoon, Y.-R.; Choi, M.-K.; Song, I.-S. Detection of 13 Ginsenosides (Rb1, Rb2, Rc, Rd, Re, Rf, Rg1, Rg3, Rh2, F1, Compound K, 20(S)-Protopanaxadiol, and 20(S)-Protopanaxatriol) in Human Plasma and Application of the Analytical Method to Human Pharmacokinetic Studies Following Two Week-Repeated Administration of Red Ginseng Extract. Molecules 2019, 24, 2618. [CrossRef]

27. Choi, M.-K.; Jin, S.; Jeon, J.-H.; Kang, W.Y.; Seong, S.J.; Yoon, Y.-R.; Han, Y.-H.; Song, I.-S. Tolerability and pharmacokinetics of ginsenosides $\mathrm{Rb} 1, \mathrm{Rb} 2, \mathrm{Rc}, \mathrm{Rd}$, and compound $\mathrm{K}$ after single or multiple administration of red ginseng extract in human beings. J. Ginseng Res. 2018, 44, 229-237. [CrossRef]

28. Chen, L.; Zhou, L.; Wang, Y.; Yang, G.; Huang, J.; Tan, Z.; Wang, Y.; Zhou, G.; Liao, J.; Ou-Yang, D.-S. Food and Sex-Related Impacts on the Pharmacokinetics of a Single-Dose of Ginsenoside Compound K in Healthy Subjects. Front. Pharmacol. 2017, 8, 636. [CrossRef]

29. Chen, Y.; Lu, Y.; Yang, Y.; Chen, X.; Zhu, L.; Zhong, D. Determination of ginsenoside compound K in human plasma by liquid chromatography-tandem mass spectrometry of lithium adducts. Acta Pharm. Sin. B 2015, 5, 461-466. [CrossRef]

30. Yang, L.; Wang, C.-Y.; Xie, X.-N.; Wang, Y.-C.; Peng, J.-B.; Huang, W.-H.; Chen, Y.; Ouyang, D.-S.; Tan, Z.-R. LC-MS/MS determination of ginsenoside compound K and its metabolite 20 (S)-protopanaxadiol in human plasma and urine: Applications in a clinical study. Bioanalysis 2019, 11, 365-380. [CrossRef]

31. Zhou, L.; Chen, L.; Wang, Y.; Huang, J.; Yang, G.; Tan, Z.; Wang, Y.; Liao, J.; Zhou, G.; Hu, K.; et al. Impact of NR1I2, adenosine triphosphate-binding cassette transporters genetic polymorphisms on the pharmacokinetics of ginsenoside compound $\mathrm{K}$ in healthy Chinese volunteers. J. Ginseng Res. 2018, 43, 460-474. [CrossRef] [PubMed]

32. Lee, P.S.; Han, J.-Y.; Song, T.W.; Sung, J.H.; Kwon, O.-S.; Song, S.; Chung, Y. Physicochemical characteristics and bioavailability of a novel intestinal metabolite of ginseng saponin (IH901) complexed with $\beta$-cyclodextrin. Int. J. Pharm. 2006, 316, 29-36. [CrossRef] [PubMed]

33. Yang, L.; Xin, J.; Zhang, Z.; Yan, H.; Wang, J.; Sun, E.; Hou, J.; Jia, X.; Lv, H. TPGS-modified liposomes for the delivery of ginsenoside compound $\mathrm{K}$ against non-small cell lung cancer: Formulation design and its evaluationin vitroandin vivo. J. Pharm. Pharmacol. 2016, 68, 1109-1118. [CrossRef] [PubMed]

34. Sawant, R.R.; Torchilin, V.P. Challenges in Development of Targeted Liposomal Therapeutics. AAPS J. 2012, 14, 303-315. [CrossRef]

35. Song, I.S.; Cha, J.-S.; Choi, M.-K. Characterization, in Vivo and in Vitro Evaluation of Solid Dispersion of Curcumin Containing d- $\alpha$-Tocopheryl Polyethylene Glycol 1000 Succinate and Mannitol. Molecules 2016, 21, 1386. [CrossRef] [PubMed]

36. Yang, L.; Zhang, Z.; Hou, J.; Jin, X.; Ke, Z.; Liu, D.; Du, M.; Jia, X.; Lv, H. Targeted delivery of ginsenoside compound K using TPGS/PEG-PCL mixed micelles for effective treatment of lung cancer. Int. J. Nanomed. 2017, 12, 7653-7667. [CrossRef] [PubMed]

37. Zhang, Y.; Tong, D.; Che, D.; Pei, B.; Xia, X.; Yuan, G.; Jin, X. Ascorbyl palmitate/d- $\alpha$-tocopheryl polyethylene glycol 1000 succinate monoester mixed micelles for prolonged circulation and targeted delivery of compound $\mathrm{K}$ for antilung cancer therapy in vitro and in vivo. Int. J. Nanomed. 2017, 12, 605-614. [CrossRef]

38. Jin, X.; Yang, Q.; Cai, N. Preparation of ginsenoside compound-K mixed micelles with improved retention and antitumor efficacy. Int. J. Nanomed. 2018, 13, 3827-3838. [CrossRef]

39. Singh, P.; Singh, H.; Castro-Aceituno, V.; Ahn, S.; Kim, Y.-J.; Yang, D.-C. Bovine serum albumin as a nanocarrier for the efficient delivery of ginsenoside compound K: Preparation, physicochemical characterizations and in vitro biological studies. RSC Adv. 2017, 7, 15397-15407. [CrossRef]

40. Kim, Y.-J.; Perumalsamy, H.; Markus, J.; Balusamy, S.R.; Wang, C.; Kang, S.H.; Lee, S.; Park, S.Y.; Kim, S.; Castro-Aceituno, V.; et al. Development of Lactobacillus kimchicus DCY51T-mediated gold nanoparticles for delivery of ginsenoside compound K: In vitro photothermal effects and apoptosis detection in cancer cells. Artif. Cells Nanomed. Biotechnol. 2019, 47, 30-44. [CrossRef]

41. Zhang, J.; Wang, Y.; Jiang, Y.; Liu, T.; Luo, Y.; Diao, E.; Cao, Y.; Chen, L.; Zhang, L.; Gu, Q.; et al. Enhanced cytotoxic and apoptotic potential in hepatic carcinoma cells of chitosan nanoparticles loaded with ginsenoside compound K. Carbohydr. Polym. 2018, 198, 537-545. [CrossRef] [PubMed] 
42. Zhang, J.; Zhou, J.; Yuan, Q.; Zhan, C.; Shang, Z.; Gu, Q.; Zhang, J.; Fu, G.; Hu, W. Characterization of ginsenoside compound $\mathrm{K}$ loaded ionically cross-linked carboxymethyl chitosan-calcium nanoparticles and its cytotoxic potential against prostate cancer cells. J. Ginseng Res. 2020. [CrossRef]

43. Zhang, J.; Jiang, Y.; Li, Y.; Li, W.; Zhou, J.; Chen, J.; Shang, Z.; Gu, Q.; Wang, W.; Shen, T.; et al. Micelles modified with a chitosan-derived homing peptide for targeted intracellular delivery of ginsenoside compound K to liver cancer cells. Carbohydr. Polym. 2019, 230, 115576. [CrossRef] [PubMed]

44. Li, G.; Yang, M.; Hao, X.; Li, C.; Gao, Y.; Tao, J. Acute toxicity of sodium formononetin-3'-sulphonate (Sul-F) in Sprague-Dawley rats and Beagle dogs. Regul. Toxicol. Pharm. 2015, 73, 629-633. [CrossRef] [PubMed]

45. Gao, Y.; Wang, T.; Wang, G.; Li, G.; Sun, C.; Jiang, Z.; Yang, J.; Li, Y.; You, Y.; Wu, X.; et al. Preclinical safety of ginsenoside compound $\mathrm{K}$ : Acute, and 26-week oral toxicity studies in mice and rats. Food Chem. Toxicol. 2019, 131, 110578. [CrossRef]

46. Li, C.; Wang, Z.; Wang, T.; Wang, G.; Li, G.; Sun, C.; Lin, J.; Sun, L.; Sun, X.; Cho, S.; et al. Repeated-dose 26-week oral toxicity study of ginsenoside compound K in Beagle dogs. J. Ethnopharmacol. 2019, 248, 112323. [CrossRef]

47. Chen, L.; Zhou, L.; Huang, J.; Wang, Y.; Yang, G.; Tan, Z.; Wang, Y.; Zhou, G.; Liao, J.; Ou-Yang, D.-S. Singleand Multiple-Dose Trials to Determine the Pharmacokinetics, Safety, Tolerability, and Sex Effect of Oral Ginsenoside Compound K in Healthy Chinese Volunteers. Front. Pharmacol. 2018, 8, 965. [CrossRef]

48. Lee, I.K.; Kang, K.A.; Lim, C.M.; Kim, K.C.; Kim, H.S.; Kim, D.-H.; Kim, B.J.; Chang, W.Y.; Hyun, J.-W.; Hyun, J.W. Compound K, a Metabolite of Ginseng Saponin, Induces Mitochondria-Dependent and Caspase-Dependent Apoptosis via the Generation of Reactive Oxygen Species in Human Colon Cancer Cells. Int. J. Mol. Sci. 2010, 11, 4916-4931. [CrossRef]

49. Xie, T.; Li, Z.; Li, B.; Sun, R.; Zhang, P.; Lv, J. Characterization of ginsenoside compound K metabolites in rat urine and feces by ultra-performance liquid chromatography with electrospray ionization quadrupole time-of-flight tandem mass spectrometry. Biomed. Chromatogr. 2019, 33, e4643. [CrossRef]

50. Li, W.; Zhang, M.; Zheng, Y.-N.; Li, J.; Wang, Y.-P.; Wang, Y.-J.; Gu, J.; Jin, Y.; Wang, H.; Chen, L. Snailase Preparation of Ginsenoside M1 from Protopanaxadiol-Type Ginsenoside and Their Protective Effects Against CCl4-Induced Chronic Hepatotoxicity in Mice. Molecules 2011, 16, 10093-10103. [CrossRef]

51. Lee, H.-U.; Bae, E.-A.; Han, M.J.; Kim, N.-J.; Kim, D.-H. Hepatoprotective effect of ginsenoside Rb1 and compound K on tert-butyl hydroperoxide-induced liver injury. Liver Int. 2005, 25, 1069-1073. [CrossRef] [PubMed]

52. Igami, K.; Shimojo, Y.; Ito, H.; Miyazaki, T.; Kashiwada, Y. Hepatoprotective effect of fermented ginseng and its major constituent compound $\mathrm{K}$ in a rat model of paracetamol (acetaminophen)-induced liver injury. J. Pharm. Pharmacol. 2014, 67, 565-572. [CrossRef] [PubMed]

53. Chen, X.-J.; Liu, W.-J.; Wen, M.-L.; Liang, H.; Wu, S.-M.; Zhu, Y.-Z.; Zhao, J.-Y.; Dong, X.-Q.; Li, M.-G.; Bian, L.; et al. Ameliorative effects of Compound $\mathrm{K}$ and ginsenoside Rh1 on non-alcoholic fatty liver disease in rats. Sci. Rep. 2017, 7, 41144. [CrossRef] [PubMed]

54. Hwang, Y.-C.; Oh, D.-H.; Choi, M.C.; Lee, S.Y.; Ahn, K.-J.; Chung, H.-Y.; Lim, S.-J.; Chung, S.H.; Jeong, I.-K. Compound $\mathrm{K}$ attenuates glucose intolerance and hepatic steatosis through AMPK-dependent pathways in type 2 diabetic OLETF rats. Korean J. Intern. Med. 2018, 33, 347-355. [CrossRef] [PubMed]

55. Choi, N.; Kim, J.W.; Jeong, H.; Shin, D.G.; Seo, J.H.; Kim, J.H.; Lim, C.W.; Han, K.M.; Kim, B. Fermented ginseng, GBCK25, ameliorates steatosis and inflammation in nonalcoholic steatohepatitis model. J. Ginseng Res. 2019, 43, 196-208. [CrossRef] [PubMed]

56. Hossen, M.J.; Hong, Y.D.; Baek, K.-S.; Yoo, S.; Hong, Y.H.; Kim, J.H.; Lee, J.-O.; Kim, D.; Park, J.; Cho, J.Y. In vitro antioxidative and anti-inflammatory effects of the compound K-rich fraction BIOGF1K, prepared from Panax ginseng. J. Ginseng Res. 2017, 41, 43-51. [CrossRef]

57. Kim, E.; Yi, Y.-S.; Son, Y.-J.; Han, S.Y.; Kim, N.H.; Nam, G.; Hossain, M.A.; Kim, J.-H.; Park, J.; Cho, J. BIOGF1K, a compound K-rich fraction of ginseng, plays an antiinflammatory role by targeting an activator protein-1 signaling pathway in RAW264.7 macrophage-like cells. J. Ginseng Res. 2018, 42, 233-237. [CrossRef]

58. Singh, H.; Du, J.; Singh, P.; Mavlonov, G.T.; Yi, T.-H. Development of superparamagnetic iron oxide nanoparticles via direct conjugation with ginsenosides and its in-vitro study. J. Photochem. Photobiol. B Biol. 2018, 185, 100-110. [CrossRef] 
59. Wang, C.W.; Huang, Y.C.; Chan, F.N.; Su, S.C.; Kuo, Y.H.; Huang, S.F.; Hung, M.W.; Lin, H.C.; Chang, W.L.; Chang, T.C. A gut microbial metabolite of ginsenosides, compound $\mathrm{K}$, induces intestinal glucose absorption and $\mathrm{Na}+$ /glucose cotransporter 1 gene expression through activation of cAMP response element binding protein. Mol. Nutr. Food Res. 2015, 59, 670-684. [CrossRef]

60. Chen, J.; Si, M.; Wang, Y.; Liu, L.; Zhang, Y.; Zhou, A.; Wei, W. Ginsenoside metabolite compound K exerts anti-inflammatory and analgesic effects via downregulating COX2. Inflammopharmacology 2018, 27, 157-166. [CrossRef]

61. Chen, J.; Wu, H.; Wang, Q.; Chang, Y.; Liu, K.; Wei, W. Ginsenoside Metabolite Compound K Suppresses T-Cell Priming via Modulation of Dendritic Cell Trafficking and Costimulatory Signals, Resulting in Alleviation of Collagen-Induced Arthritis. J. Pharmacol. Exp. Ther. 2015, 353, 71-79. [CrossRef] [PubMed]

62. Lee, Y.J.; Song, K.Y.; Lee, E.Y.; Kang, H.S.; Song, Y. Compound K, a Metabolite of Ginsenosides, Attenuates Collagen-induced Arthritis in Mice. J. Rheum. Dis. 2015, 22, 154-166. [CrossRef]

63. Chen, J.; Wang, Q.; Wu, H.; Liu, K.; Wu, Y.; Chang, Y.; Wei, W. The ginsenoside metabolite compound K exerts its anti-inflammatory activity by downregulating memory B cell in adjuvant-induced arthritis. Pharm. Biol. 2016, 54, 1-9. [CrossRef] [PubMed]

64. Wang, R.; Zhang, M.; Hu, S.; Liu, K.; Tai, Y.; Tao, J.; Zhou, W.; Zhao, Z.; Wang, Q.; Wei, W. Ginsenoside metabolite compound-K regulates macrophage function through inhibition of $\beta$-arrestin2. Biomed. Pharmacother. 2019, 115, 108909. [CrossRef]

65. Kang, S.; Siddiqi, M.H.; Yoon, S.J.; Ahn, S.; Noh, H.-Y.; Kumar, N.S.; Kim, Y.-J.; Yang, D.-C. Therapeutic potential of compound $\mathrm{K}$ as an IKK inhibitor with implications for osteoarthritis prevention: An in silico and in vitro study. Vitr. Cell. Dev. Biol. Anim. 2016, 52, 895-905. [CrossRef] [PubMed]

66. Liu, Y.; Perumalsamy, H.; Kang, C.H.; Kim, S.H.; Hwang, J.-S.; Koh, S.-C.; Yi, T.-H.; Kim, Y.-J. Intracellular synthesis of gold nanoparticles by Gluconacetobacter liquefaciens for delivery of peptide CopA3 and ginsenoside and anti-inflammatory effect on lipopolysaccharide-activated macrophages. Artif. Cell. Nanomed. B 2020, 48, 777-788. [CrossRef] [PubMed]

67. Zhou, L.; Zheng, Y.; Li, Z.; Bao, L.; Dou, Y.; Tang, Y.; Zhang, J.; Zhou, J.; Liu, Y.; Jia, Y.; et al. Compound K Attenuates the Development of Atherosclerosis in ApoE-/- Mice via LXR $\alpha$ Activation. Int. J. Mol. Sci. 2016, 17, 1054. [CrossRef]

68. Huang, Y.; Liu, H.; Zhang, Y.; Li, J.; Wang, C.; Zhou, L.; Jia, Y.; Li, X. Synthesis and Biological Evaluation of Ginsenoside Compound K Derivatives as a Novel Class of LXR $\alpha$ Activator. Molecules 2017, 22, 1232. [CrossRef]

69. Lu, S.; Luo, Y.; Zhou, P.; Yang, K.; Sun, G.; Sun, X. Ginsenoside compound K protects human umbilical vein endothelial cells against oxidized low-density lipoprotein-induced injury via inhibition of nuclear factor- $\mathrm{kB}$, p38, and JNK MAPK pathways. J. Ginseng Res. 2017, 43, 95-104. [CrossRef]

70. Wei, S.; Li, W.; Yu, Y.; Yao, F.; Lixiang, A.; Lan, X.; Guan, F.; Zhang, M.; Chen, L. Ginsenoside Compound K suppresses the hepatic gluconeogenesis via activating adenosine- $5^{\prime}$ monophosphate kinase: A study in vitro and in vivo. Life Sci. 2015, 139, 8-15. [CrossRef]

71. Chen, W.; Wang, J.; Luo, Y.; Wang, T.; Li, X.; Li, A.; Li, J.; Liu, K.; Liu, B. Ginsenoside Rb1 and compound $\mathrm{K}$ improve insulin signaling and inhibit ER stress-associated NLRP3 inflammasome activation in adipose tissue. J. Ginseng Res. 2015, 40, 351-358. [CrossRef] [PubMed]

72. Nam, Y.H.; Le, H.T.; Rodriguez, I.; Kim, E.Y.; Kim, K.; Jeong, S.Y.; Woo, S.H.; Lee, Y.R.; Castañeda, R.; Hong, J.; et al. Enhanced antidiabetic efficacy and safety of compound $\mathrm{K} / \beta$-cyclodextrin inclusion complex in zebrafish. J. Ginseng Res. 2016, 41, 103-112. [CrossRef] [PubMed]

73. Song, W.; Wei, L.; Du, Y.; Wang, Y.; Jiang, S. Protective effect of ginsenoside metabolite compound K against diabetic nephropathy by inhibiting NLRP3 inflammasome activation and NF-kB/p38 signaling pathway in high-fat diet/streptozotocin-induced diabetic mice. Int. Immunopharmacol. 2018, 63, 227-238. [CrossRef] [PubMed]

74. Metwaly, A.M.; Lianlian, Z.; Huang, L.-Q.; Dou, D. Black Ginseng and Its Saponins: Preparation, Phytochemistry and Pharmacological Effects. Molecules 2019, 24, 1856. [CrossRef]

75. Wang, R.; Li, Y.; Wang, W.; Zhou, M.; Cao, Z. [Compound K suppresses myeloid-derived suppressor cells in a mouse model bearing CT26 colorectal cancer xenograft]. Nan fang yi ke da xue xue bao =J. South. Med. Univ. 2015, 35, 748-752. 
76. Lee, S.; Kwon, M.C.; Jang, J.-P.; Sohng, J.K.; Jung, H.J. The ginsenoside metabolite compound K inhibits growth, migration and stemness of glioblastoma cells. Int. J. Oncol. 2017, 51, 414-424. [CrossRef]

77. Kwak, C.W.; Son, Y.M.; Gu, M.J.; Kim, G.; Lee, I.K.; Kye, Y.C.; Kim, H.W.; Song, K.D.; Chu, H.; Park, B.-C.; et al. A Bacterial Metabolite, Compound K, Induces Programmed Necrosis in MCF-7 Cells via GSK3ß. J. Microbiol. Biotechnol. 2015, 25, 1170-1176. [CrossRef]

78. Zhang, K.; Li, Y. Effects of ginsenoside compound K combined with cisplatin on the proliferation, apoptosis and epithelial mesenchymal transition in MCF-7 cells of human breast cancer. Pharm. Biol. 2015, 54, 561-568. [CrossRef]

79. Lee, S.J.; Lee, J.S.; Lee, E.; Lim, T.-G.; Byun, S. The ginsenoside metabolite compound K inhibits hormone-independent breast cancer through downregulation of cyclin D1. J. Funct. Foods 2018, 46, 159-166. [CrossRef]

80. Li, K.-K.; Yan, X.-M.; Li, Z.-N.; Yan, Q.; Gong, X.-J. Synthesis and antitumor activity of three novel ginsenoside M1 derivatives with 3'-ester modifications. Bioorg. Chem. 2019, 90, 103061. [CrossRef]

81. Choi, E.; Kim, E.; Kim, J.H.; Yoon, K.; Kim, S.; Lee, J.; Cho, J. AKT1-targeted proapoptotic activity of compound $\mathrm{K}$ in human breast cancer cells. J. Ginseng Res. 2019, 43, 692-698. [CrossRef] [PubMed]

82. Li, C.; Dong, Y.; Wang, L.; Xu, G.; Yang, Q.; Tang, X.; Qiao, Y.; Cong, Z. Ginsenoside metabolite compound K induces apoptosis and autophagy in non-small cell lung cancer cells via AMPK-mTOR and JNK pathways. Biochem. Cell Biol. 2019, 97, 406-414. [CrossRef] [PubMed]

83. Chen, H.-F.; Wu, L.-X.; Li, X.-F.; Zhu, Y.-C.; Wang, W.-X.; Xu, C.-W.; Huang, Z.-Z.; Du, K.-Q. Ginsenoside compound $\mathrm{K}$ inhibits growth of lung cancer cells via HIF-1 $\alpha$-mediated glucose metabolism. Cell. Mol. Biol. 2019, 65, 48-52. [CrossRef]

84. Dong, X.; Han, H.; Shi, H.; Wang, T.; Wang, B.; Zhao, J. Compound K, a metabolite of ginseng saponin, induces apoptosis of hepatocellular carcinoma cells through the mitochondria-mediated caspase-dependent pathway. Int. J. Clin. Exp. Med. 2017, 10, 11146-11156.

85. Zhang, X.; Zhang, S.; Sun, Q.; Jiao, W.; Yan, Y.; Zhang, X. Compound K Induces Endoplasmic Reticulum Stress and Apoptosis in Human Liver Cancer Cells by Regulating STAT3. Molecules 2018, 23, 1482. [CrossRef]

86. Wang, Y.-S.; Zhu, H.; Li, H.; Li, Y.; Zhao, B.; Jin, Y.-H. Ginsenoside compound K inhibits nuclear factor-kappa B by targeting Annexin A2. J. Ginseng Res. 2018, 43, 452-459. [CrossRef]

87. Shin, D.-H.; Leem, D.-G.; Shin, J.-S.; Kim, J.-I.; Kim, K.-T.; Choi, S.Y.; Lee, M.-H.; Choi, J.-H.; Lee, K.-T. Compound $\mathrm{K}$ induced apoptosis via endoplasmic reticulum $\mathrm{Ca} 2+$ release through ryanodine receptor in human lung cancer cells. J. Ginseng Res. 2017, 42, 165-174. [CrossRef]

88. Chen, L.; Meng, Y.; Sun, Q.; Zhang, Z.; Guo, X.; Sheng, X.; Tai, G.; Cheng, H.; Zhou, Y. Ginsenoside compound $\mathrm{K}$ sensitizes human colon cancer cells to TRAIL-induced apoptosis via autophagy-dependent and -independent DR5 upregulation. Cell Death Dis. 2016, 7, e2334. [CrossRef]

89. Kim, H.; Roh, H.S.; Kim, J.E.; Park, S.D.; Park, W.H.; Moon, J.-Y. Compound K attenuates stromal cell-derived growth factor 1 (SDF-1)-induced migration of C6 glioma cells. Nutr. Res. Pr. 2016, 10, 259-264. [CrossRef]

90. Chen, K.; Jiao, J.; Xue, J.; Chen, T.; Hou, Y.; Jiang, Y.; Qian, L.; Wang, Y.; Ma, Z.; Liang, Z.; et al. Ginsenoside $\mathrm{CK}$ induces apoptosis and suppresses proliferation and invasion of human osteosarcoma cells through the PI3K/mTOR/p70S6K1 pathway. Oncol. Rep. 2020, 43, 886-896. [CrossRef]

91. Jin, X.; Zhou, J.; Zhang, Z.; Lv, H. The combined administration of parthenolide and ginsenoside CK in long circulation liposomes with targeted tLyp-1 ligand induce mitochondria-mediated lung cancer apoptosis. Artif. Cells Nanomed. Biotechnol. 2018, 46, S931-S942. [CrossRef] [PubMed]

92. Darsandhari, S.; Shrestha, B.; Pandey, R.P.; Lee, S.; Jung, H.J.; Kim, Y.-J.; Sohng, J.K. Enzymatically Synthesized Ginsenoside Exhibits Antiproliferative Activity in Various Cancer Cell Lines. Appl. Sci. 2019, 9, 893. [CrossRef]

93. Seo, J.Y.; Ju, S.H.; Oh, J.; Lee, S.K.; Kim, J.-S. Neuroprotective and Cognition-Enhancing Effects of Compound K Isolated from Red Ginseng. J. Agric. Food Chem. 2016, 64, 2855-2864. [CrossRef] [PubMed]

94. Li, C.-W.; Deng, M.-Z.; Gao, Z.-J.; Dang, Y.-Y.; Zheng, G.-D.; Yang, X.-J.; Chao, Y.-X.; Cai, Y.-F.; Wu, X.-L. Effects of compound $\mathrm{K}$, a metabolite of ginsenosides, on memory and cognitive dysfunction in $\mathrm{db} / \mathrm{db}$ mice involve the inhibition of ER stress and the NLRP3 inflammasome pathway. Food Funct. 2020, 11, 4416-4427. [CrossRef] [PubMed]

95. Yayeh, T.; Yun, K.; Jang, S.; Oh, S. Morphine dependence is attenuated by red ginseng extract and ginsenosides Rh2, Rg3, and compound K. J. Ginseng Res. 2016, 40, 445-452. [CrossRef] 
96. Zeng, X.; Hu, K.; Chen, L.; Zhou, L.; Luo, W.; Li, C.; Zong, W.; Chen, S.; Gao, Q.; Zeng, G.; et al. The Effects of Ginsenoside Compound K Against Epilepsy by Enhancing the $\gamma$-Aminobutyric Acid Signaling Pathway. Front. Pharmacol. 2018, 9, 9. [CrossRef]

97. Liu, Q.; Liu, L.; Liu, H.; Jiang, J.; Guo, S.; Wang, C.; Jia, Y.; Tian, Y. Compound K attenuated hepatectomyinduced post-operative cognitive dysfunction in aged mice via $\mathrm{LXR} \alpha$ activation. Biomed. Pharmacother. 2019, 119, 109400. [CrossRef]

98. Yang, Q.; Lin, J.; Zhang, H.; Liu, Y.; Kan, M.; Xiu, Z.; Chen, X.; Lan, X.; Li, X.; Shi, X.; et al. Ginsenoside compound $\mathrm{K}$ regulates amyloid $\beta$ via the Nrf2/Keap1 signaling pathway in mice with scopolamine hydrobromide-induced memory impairments. J. Mol. Neurosci. 2019, 67, 62-71. [CrossRef]

99. Chen, X.; Li, H.; Yang, Q.; Lan, X.; Wang, J.; Cao, Z.; Shi, X.; Li, J.; Kan, M.; Qu, X.; et al. Ginsenoside compound K ameliorates Alzheimer's disease in HT22 cells by adjusting energy metabolism. Mol. Biol. Rep. 2019, 46, 5323-5332. [CrossRef]

100. Zong, W.; Zeng, X.; Chen, S.; Chen, L.; Zhou, L.; Wang, X.; Gao, Q.; Zeng, G.; Hu, K.; Ou-Yang, D.-S. Ginsenoside compound $\mathrm{K}$ attenuates cognitive deficits in vascular dementia rats by reducing the $\mathrm{A} \beta$ deposition. J. Pharmacol. Sci. 2019, 139, 223-230. [CrossRef]

101. Jiang, S.; Zhang, H.; Qian, M.; Su, X.; Sun, X.; Wu, T.; Song, W. Effects of ginsenoside CK pretreatment on oxidative stress and inflammation in rats with cerebral ischemia/reperfusion injury. Biotechnol. Biotechnol. Equip. 2018, 32, 1606-1612. [CrossRef]

102. Song, W.; Guo, Y.; Jiang, S.; Wei, L.; Liu, Z.; Wang, X.; Su, Y. Antidepressant Effects of the Ginsenoside Metabolite Compound K, Assessed by Behavioral Despair Test and Chronic Unpredictable Mild Stress Model. Neurochem. Res. 2018, 43, 1371-1382. [CrossRef] [PubMed]

103. Song, W.; Li, G.; Tang, Y.; Wei, L.; Song, D.; Wang, X.; Zhang, C.; Jin, X.; Jiang, S. Ginsenoside compound K inhibits oxidative stress and NLRP3 inflammasome activity in mice exposed to chronic unpredictable mild stress. Biotechnol. Biotechnol. Equip. 2019, 33, 1372-1379. [CrossRef]

104. Zhou, L.; Yang, F.; Yin, J.-W.; Gu, X.; Xu, Y.; Liang, Y.-Q. Compound K induces neurogenesis of neural stem cells in thrombin induced nerve injury through $\mathrm{LXR} \alpha$ signaling in mice. Neurosci. Lett. 2020, 729, 135007. [CrossRef]

105. Oh, J.-M.; Jeong, J.H.; Park, S.Y.; Chun, S. Ginsenoside Compound K Induces Adult Hippocampal Proliferation and Survival of Newly Generated Cells in Young and Elderly Mice. Biomolecules 2020, 10, 484. [CrossRef]

106. Lim, T.-G.; Jeon, A.J.; Yoon, J.H.; Song, D.; Kim, J.-E.; Kwon, J.Y.; Kim, J.R.; Kang, N.J.; Park, J.-S.; Yeom, M.H.; et al. 20-O- $\beta$-D-glucopyranosyl-20(S)-protopanaxadiol, a metabolite of ginsenoside Rb1, enhances the production of hyaluronic acid through the activation of ERK and Akt mediated by Src tyrosin kinase in human keratinocytes. Int. J. Mol. Med. 2015, 35, 1388-1394. [CrossRef]

107. Kim, E.; Kim, N.; Yoo, S.; Hong, Y.H.; Han, S.Y.; Jeong, S.; Jeong, D.; Kim, J.-H.; Cho, J.; Park, J. The skin protective effects of compound $\mathrm{K}$, a metabolite of ginsenoside Rb1 from Panax ginseng. J. Ginseng Res. 2017, 42, 218-224. [CrossRef]

108. Hong, Y.H.; Kim, N.; Nam, G.; Yoo, S.; Han, S.Y.; Jeong, S.-G.; Kim, E.; Jeong, D.; Yoon, K.; Kim, S.; et al. Photoaging protective effects of BIOGF1K, a compound-K-rich fraction prepared from Panax ginseng. J. Ginseng Res. 2017, 42, 81-89. [CrossRef]

109. Lee, S.Y. Synergistic effect of maclurin on ginsenoside compound K induced inhibition of the transcriptional expression of matrix metalloproteinase-1 in HaCaT human keratinocyte cells. J. Ginseng Res. 2017, 42, 229-232. [CrossRef]

110. Park, N.-J.; Bong, S.-K.; Lee, S.; Jung, Y.; Jegal, H.; Kim, J.; Kim, S.-K.; Kim, Y.K.; Kim, S.-N. Compound K improves skin barrier function by increasing SPINK5 expression. J. Ginseng Res. 2019. [CrossRef]

111. Fan, H.; Wang, Y.; Zhang, X.; Chen, J.; Zhou, Q.; Yu, Z.; Chen, Y.; Chen, Z.; Gu, J.; Shi, Y. Ginsenoside compound $\mathrm{K}$ ameliorates imiquimod-induced psoriasis-like dermatitis through inhibiting REG3A/RegIII $\gamma$ expression in keratinocytes. Biochem. Biophys. Res. Commun. 2019, 515, 665-671. [CrossRef] [PubMed]

112. Hsu, W.-H.; Hua, K.-F.; Tuan, L.-H.; Tsai, Y.-L.; Chu, L.J.; Lee, Y.-C.; Wong, W.-T.; Lee, S.-L.; Lai, J.-H.; Chu, C.-L.; et al. Compound $\mathrm{K}$ inhibits priming and mitochondria-associated activating signals of NLRP3 inflammasome in renal tubulointerstitial lesions. Nephrol. Dial. Transplant. 2019, 35, 74-85. [CrossRef]

113. Lin, T.-J.; Wu, C.-Y.; Tsai, P.-Y.; Hsu, W.-H.; Hua, K.-F.; Chu, C.-L.; Lee, Y.-C.; Chen, A.; Lee, S.-L.; Lin, Y.-J.; et al. Accelerated and Severe Lupus Nephritis Benefits From M1, an Active Metabolite of Ginsenoside, by Regulating NLRP3 Inflammasome and T Cell Functions in Mice. Front. Immunol. 2019, 10, 1951. [CrossRef] 
114. Ren, S.; Liu, R.; Wang, Y.; Ding, N.; Li, Y. Synthesis and biological evaluation of Ginsenoside Compound K analogues as a novel class of anti-asthmatic agents. Bioorg. Med. Chem. Lett. 2019, 29, 51-55. [CrossRef]

115. Li, X.; Huang, Q.; Wang, M.; Yan, X.; Song, X.; Ma, R.; Jiang, R.; Zhao, D.; Sun, L. Compound K Inhibits Autophagy-Mediated Apoptosis Through Activation of the PI3K-Akt Signaling Pathway Thus Protecting Against Ischemia/Reperfusion Injury. Cell. Physiol. Biochem. 2018, 47, 2589-2601. [CrossRef]

116. Bessell, E.; Fuller, N.R.; Markovic, T.P.; Burk, J.; Picone, T.; Hendy, C.; Tan, M.M.C.; Caterson, I.D. Effects of alpha-cyclodextrin on cholesterol control and Compound $\mathrm{K}$ on glycaemic control in people with pre-diabetes: Protocol for a Phase III randomized controlled trial. Clin. Obes. 2019, 9, e12324. [CrossRef] [PubMed]

117. Oh, M.-R.; Park, S.-H.; Kim, S.-Y.; Baek, H.-I.; Kim, M.-G.; Jeon, J.-Y.; Ha, K.-C.; Na, W.-T.; Cha, Y.-S.; Park, B.-H.; et al. Postprandial glucose-lowering effects of fermented red ginseng in subjects with impaired fasting glucose or type 2 diabetes: A randomized, double-blind, placebo-controlled clinical trial. BMC Complement. Altern. Med. 2014, 14, 237. [CrossRef] [PubMed]

118. Flanagan, S.D.; Dupont, W.H.; Caldwell, L.K.; Hardesty, V.H.; Barnhart, E.C.; Beeler, M.K.; Post, E.M.; Volek, J.S.; Kraemer, W.J. The Effects of a Korean Ginseng, GINST15, on Hypo-Pituitary-Adrenal and Oxidative Activity Induced by Intense Work Stress. J. Med. Food 2018, 21, 104-112. [CrossRef] [PubMed]

119. Flanagan, S.D.; Proessl, F.; Dunn-Lewis, C.; Canino, M.C.; Sterczala, A.J.; Connaboy, C.; Dupont, W.H.; Caldwell, L.K.; Kraemer, W.J. Constitutive and Stress-Induced Psychomotor Cortical Responses to Compound K Supplementation. Front. Neurosci. 2020, 14, 315. [CrossRef] [PubMed]

120. Jung, S.-J.; Hwang, J.-H.; Park, S.-H.; Choi, E.-K.; Ha, K.-C.; Baek, H.-I.; Shin, D.-G.; Seo, J.-H.; Chae, S.-W. A 12-week, randomized, double-blind study to evaluate the efficacy and safety of liver function after using fermented ginseng powder (GBCK25). Food Nutr. Res. 2020, 64, 3517. [CrossRef]

(C) 2020 by the authors. Licensee MDPI, Basel, Switzerland. This article is an open access article distributed under the terms and conditions of the Creative Commons Attribution (CC BY) license (http://creativecommons.org/licenses/by/4.0/). 